\title{
AGRONOMIC ASPECTS OF SWITCHGRASS CULTIVATION AND USE FOR ENERGY PURPOSES
}

\author{
BRODOWSKA, M. S. ${ }^{1}$ - MUSZYŃSKI, P. ${ }^{2 *}-$ HALINIARZ, M. ${ }^{3}$ - BrodOWSKI, R. ${ }^{4}-$ KOWALCZYK- \\ JUŚKO, A. ${ }^{4}-$ SEKUTOWSKI, T. ${ }^{5}-$ KURZYNA-SZKLAREK, $M .{ }^{1}$ \\ ${ }^{I}$ Department of Agricultural and Environmental Chemistry, University of Life Sciences in \\ Lublin, Akademicka Street 15, 20-950 Lublin, Poland \\ (phone: +48-81-445-6045) \\ ${ }^{2}$ Department of Chemistry, University of Life Sciences in Lublin \\ Akademicka Street 15, 20-950 Lublin, Poland \\ (phone: +48-81-445-6556) \\ ${ }^{3}$ Department of Herbology and Plant Cultivation Techniques, University of Life Science in \\ Lublin, Akademicka Street 13, 20-950 Lublin, Poland \\ (phone: +48-81-445-6654) \\ ${ }^{4}$ Department of Environmental Engineering and Geodesy, University of Life Sciences in Lublin \\ Leszczyńskiego Street 7, 20-069 Lublin, Poland \\ (phone: +48-81-531-9712) \\ ${ }^{5}$ Department of Weed Science and Tillage Systems, Institute of Soil Science and Plant \\ Cultivation, National Research Institute, Orzechowa Street 61, 50-540 Wroctaw, Poland \\ (phone: +48-71-336-2658) \\ *Corresponding author \\ e-mail:pawel.muszynski@up.lublin.pl; phone:+48-81-445-6556 \\ (Received 22 $2^{\text {nd }}$ Jun 2018; accepted $9^{\text {th }}$ Aug 2018)
}

\begin{abstract}
The world's non-renewable energy resources continually decline and therefore there is an urgent need to seek and use any available renewable energy sources. An alternative to conventional fuels can be the usage of plant biomass for energy purposes. This particularly relates to plants with $\mathrm{C} 4$ photosynthesis, a large increase in biomass, low habitat requirements, and high resistance to diseases and pests. All these characteristics are met, among others, by switchgrass which in many countries occurs as a common wild plant. In agricultural production, switchgrass does not pose many agronomic problems; moreover, it is a very durable plant that can be used in one stand for even 10 years and can be grown in all soils, even contaminated ones. Effective use of switchgrass for bioethanol, biogas or syngas production provides measurable ecological benefits and in the long term offers a chance to maintain a sustainable national energy balance, given the continuously shrinking non-renewable fuel resources. Due to the multifaceted use of this plant and a number of features important from the point of view of the power generation industry, it is worth having a closer look at the possibility of spreading the cultivation of this species.
\end{abstract}

Keywords: Panicum virgatum, cropping, biomass, combustion and co-firing, biofuels

\section{Introduction}

Switchgrass (Panicum virgatum L.) belongs to the Poaceae family. It is native to North America where it occurs naturally from the Atlantic coast to the Rocky Mountains within the area between $55^{\circ} \mathrm{N}$ (southern Canada) and $30^{\circ} \mathrm{N}$ (northern Mexico) (Lewandowski et al., 2003; Wullschleger et al., 2010). This is a perennial grass with erect stems, often with a reddish tinge, and a height from 0.5 to $2.7 \mathrm{~m}$. The 
inflorescence is a branched panicle with a length from 15 to $50 \mathrm{~cm}$. Switchgrass has a very well-developed root system that reaches a depth of even 3 meters (Moser and Vogel, 1995; Christian and Elbersen, 1998; Vogel et al., 2011; Kibet et al., 2016). It is a species with C4 photosynthesis (Hatch-Slack cycle) and due to this it can carry out this process even four times more efficiently compared to C3 type plants (Gołaszewski, 2011; Wang et al., 2012).

Due to the different morphological characteristics and habitat preferences, two ecotypes of this species are distinguished: the lowland ecotype and the upland ecotype (Bals et al., 2010; Casler, 2012; Young et al., 2012). Lowland ecotypes reach a height of more than $3 \mathrm{~m}$, usually grow in clumps in wetland areas, and have thick stiff stems with a large number of branches. Upland ecotypes are shorter, occur in dry areas, have thinner stems with a lower number of branches compared to lowland switchgrass, and form characteristic sods; they are more recommended for growing in a cooler climate (Christensen and Koppenjan, 2010; Casler, 2012).

The first attempts to grow switchgrass began in the 30s and 40s of the 20th century in the USA where many switchgrass cultivars have been bred, including several cultivars also adapted to European climatic conditions: 'Cave-in-Rock', 'Kanlow', and 'Alamo' (McLaughlin and Kszos, 2005). In the United States, this species is recommended for sodding in degraded areas and is grown as an erosion prevention plant. Moreover, switchgrass has the ability to clean soils and waters by removing excess nutrients (N, P) originating, among others, from fertilization. Switchgrass filter strips decrease the amount of reactive phosphorus and reduce the chemical oxygen demand (COD) in surface runoff water, which protects surface waters against eutrophication (Sanderson and Adler, 2008). Switchgrass is used for phytoremediation because it exhibits the capacity to accumulate toxic substances from soils, in particular heavy metals and residues of crop protection chemicals (Chen et al., 2012; Zorer Çelebi and Zorer, 2018). The capacity of switchgrass for significant soil carbon sequestration contributes to a reduction in total environmental $\mathrm{CO}_{2}$ balance (Liebig et al., 2008; Adkins et al., 2016). This plant is also an excellent growth and living habitat for wildfowl and mammals, in particular in the so-called ecotone zones between forest and crop fields. It is also a very impressive and beautiful ornamental grass sown in gardens and parks (Dudkiewicz and Bolibok, 2011; Elbersen et al., 2013).

At the beginning of the 90s of the last century, an attempt was also made to use switchgrass as an energy crop. The U.S. Department of Energy, among others, conducted research on the use of biomass of this species for energy purposes. Also in Europe, switchgrass arouses an increasingly greater interest as a productive and durable 'energy' species resistant to adverse environmental conditions (Bals et al., 2010; Sanderson and Adler, 2008; Wullschleger et al., 2010). Due to the multifaceted use of this plant and a number of features important from the point of view of the power generation industry, it is worth having a closer look at the possibility of introducing and spreading the cultivation of this species (Bocian et al., 2010; Pszczółkowski et al., 2012).

\section{Plantation establishment and management}

\section{Sowing of switchgrass}

Switchgrass seeds are very small (depending on the cultivar, 500-1000 seeds $\cdot \mathrm{g}^{-1}$ ) and characterized by very short viability and low germination capacity. The field emergence 
rate is about 50\% (Schmer et al., 2006). To increase their germination capacity, switchgrass seeds should be stratified by subjecting them to low temperatures or $\mathrm{NaClO}$. The recommended seeding depth is from 0.5 to $2.0 \mathrm{~cm}$ (Sanderson et al., 2012). In wet areas, it is recommended to grow switchgrass with a row spacing of $60-90 \mathrm{~cm}$, while in dry areas 90-120 cm (Majtkowski, 2006). It has been shown that switchgrass germinates better and besides the growth of seedlings is more intensive after application of selected strains of Cyanobacteria, which have the ability to fix atmospheric nitrogen, as a biofertilizer (Chojnacka et al., 2010). Switchgrass is not resistant to low temperatures and this is why it should be sown in areas with mild winters. Its seeds sprout best in a soil with a pH ranging 6-8 (Hanson and Johnson, 2005).

The field under switchgrass should be very carefully prepared. Switchgrass can be sown in no-till or conventional cultivation practices. No-till allows you to set up switchgrass plantations on fields with a large slope and in areas with low rainfall (Drinnon et al., 2014; Sadeghpour et al., 2014b). Moreover, according to Ashworth et al. (2015) intercropping selected legumes in switchgrass may enhance forage quality and yield, reduce fertilizer costs, and emissions/runoff to air and groundwater.

\section{Plantation evaluation in terms of emergence}

The first evaluation of the condition of a plantation is conducted after 6-10 weeks from the date of its establishment. At this time, the number of seedlings per $1 \mathrm{~m}^{2}$ should be from 100 to 200. The second evaluation of the condition of the plantation is made at the end of the first growing season. To conclude that the plantation has been successfully established, there should be 10-30 plants per $\mathrm{m}^{2}$ (Douglas et al., 2009). Due to intensive tillering, plants growing at a lower density in the first year will produce a larger number of stems in the next years.

\section{Weed control}

One of the major factors that ensure optimal growth and development of switchgrass intended for energy production is to eliminate or at least reduce weed infestation of a plantation, mainly in the first year (Miesel et al., 2012). The slow growth rate of switchgrass (during the first month) and the late time of its sowing (the second decade of April and the beginning of May) promote weed competition. The greatest noxiousness of weeds is observed during the period from emergence to the 8-10-leaf stage of switchgrass (Boydston et al., 2010; Anderson et al., 2014).

Switchgrass badly bears cutting (especially in the first year of cultivation) and damage that can occur during mechanical weed control treatments and therefore mechanical and physical methods are not recommended in switchgrass cultivation. Chemical weed control in switchgrass crops is limited by the small range of agents recommended for use in non-agricultural crops used for energy purposes. The effect of such weed control is partial, since predominantly the annual (mono- and dicotyledonous) species are well destroyed, whereas the perennial deep-rooted species are poorly destroyed and in the next year (during the plant establishment period) they reappear, very frequently with double intensity. Furthermore, inappropriately selected herbicides can produce the following adverse effects: decreased field germination capacity, damage of switchgrass plants, and their reduced biomass (Sekutowski et al., 2009; Boydston et al., 2010; Anderson et al., 2014). A year before the establishment of a switchgrass plantation, it is recommended to use different herbicides that contain in 
their composition mainly glyphosate (following Smeets et al., 2009). According to Bullard and Metcalfe (2001), the optimal rate of glyphosate in switchgrass cultivation is $2.5 \mathrm{~kg} \cdot \mathrm{ha}^{-1}$. To control dicotyledonous weeds, herbicides with bentazon and 2,4-D can also be used (Samson, 2007; Christensen and Koppenjan, 2010; Scordia et al., 2015). In the professional literature, there is little information and few recommendations concerning weed management in switchgrass plantations using foliar herbicides. The present author's research conducted since 2008 shows that it is possible to use selectively and safely various foliar herbicides recommended for use in cereal, maize or green crops (Table 1).

Table 1. Exemplary active substances of herbicides used in the cultivation of switchgrass. (Own results not published)

\begin{tabular}{c|c|c|c|c|c}
\hline \multirow{2}{*}{ Active substance } & \multirow{2}{*}{$\begin{array}{c}\text { Application } \\
\text { date }\end{array}$} & \multicolumn{2}{|c|}{ F } & \multicolumn{2}{c}{ Weed management } \\
\cline { 3 - 6 } & I & II & Monocotyledons & Dicotyledonous \\
\hline $\begin{array}{c}\text { Iodosulfuron-methyl-sodium; } \\
\text { Mesosulfuron-methyl }\end{array}$ & $\mathrm{T}-3$ & $2-3(\mathrm{CH})$ & $1-2$ & + & + \\
\hline $\begin{array}{c}\text { Thifensulfuron methyl; } \\
\text { Chlorsulfuron }\end{array}$ & $\mathrm{T}-3$ & $2(\mathrm{CH})$ & 1 & + & + \\
\hline MCPA & $\mathrm{T}-3$ & 1 & 1 & - & + \\
\hline 2,4-D; Dicamba & $\mathrm{T}-3$ & 1 & 1 & - & + \\
\hline Clopyralid; Fluroxypyr; Triclopyr & $\mathrm{T}-3$ & 1 & 1 & - & + \\
\hline
\end{tabular}

F - phytotoxicity - sensitivity to the active substance of the herbicide in a 1-9 scale, where: 1 - no effect on switchgrass, 9 - complete destruction of switchgrass; I - 7 days after application of the active substance of the herbicide; II - 28 days after application of the active substance of the herbicide; $\mathrm{CH}-$ leaf chlorosis; T-3 - 3-5 switchgrass leaves

\section{Switchgrass insects}

Switchgrass is genetically varied and generally resistant to many insects and hence pests usually do not pose a problem in growing switchgrass. Damage caused by insects can be much greater when switchgrass monocultures are grown on large production fields (Sanderson et al., 2012). The most common insects found were Coleoptera, Hemiptera, Diptera and Hymenoptera (Parrish and Fike, 2005; Holguin, 2010).

In the northern states of the USA, Prasifka et al. (2010) recorded the occurrence of Blastobasis repartella on a wildly growing switchgrass. Larvae of this moth feed on young tillers of switchgrass. In South Dakota (USA) Boe and Gagne (2011) discovered on switchgrass new species of gall midge. Sometimes plantations of switchgrass can be damaged by grasshoppers and crickets (Orthoptera) (Parrish and Fike, 2005; Branson et al., 2006; Holguin, 2010).

Management of pests in grasses involves mainly chemical control. With high pest incidence, insecticides based on malathion and carbaryl, insect growth regulators and pyrethroids are used (Holguin, 2010).

\section{Switchgrass diseases}

In wet locations, switchgrass can be infected by fungal diseases, but lowland types are more resistant to rust than upland ones. Especially young plantations can be sometimes attacked by various diseases (Vogel et al., 2011; Uppalapati et al., 2013). 
Rust is the biggest problem in growing switchgrass. Two species of rust fungi, Uromyces graminicola and Puccinia emaculata, are known to infect switchgrass (Gustafson et al., 2003; Zale et al., 2008; Sanderson et al., 2012; Uppalapati et al., 2013). Rust can be controlled by fungicides, however, some of them negatively affect the quality of the raw material obtained. Hagan and Akridge (2013) achieved the best results by applying azoxystrobin and myclobutanil. A very good way to protect the plantation against rust is also the cultivation of varieties resistant to these pathogens (Gustafson et al., 2003).

Switchgrass may also be attacked by diseases such as: anthracnose (Colletotricum navitas), smuts (Tilletia maclaganii), Phoma leaf spot (Phoma spp.), and Fursarium root rot (Fusarium spp.), sharp eyespot (Rhizoctonia cerealis), leaf spot (Colletotrichum graminicola), bunt (Tilletia pulcherrima), spot blotch and root rot (Bipolaris spicifera) (Vogel, 2004; Carris et al., 2008; Crouch et al., 2010; Vu et al., 2011). In Iowa (USA) Thomsen et al. (2008) estimated yield losses from Tilletia maclaganii of 2-40\% in switchgrass fields. Leaf spot is caused by fungi from the genus Bipolaris. This disease reduces seed germination and yield of switchgrass biomass, particularly if a susceptible cultivar is seeded over a wide area. Control measures against leaf spots include developing resistant cultivars and fungicidal seed treatments (Krupinsky et al., 2004). According to research of Steward et al. (2015) viral diseases raised by Panicum mosaic virus and its satellite virus should be considered important pathogens of switchgrass and serious potential threats to biofuel crop production efficiency.

\section{Fertilization}

Switchgrass does not have high soil requirements. Even though it prefers soils with a neutral $\mathrm{pH}$, but it also grows well in slightly acidic and alkaline soils. It can be grown on light or medium cohesive, moderately salinated and agriculturally unsuitable soils (Evanylo et al., 2005; Kabała et al., 2010; Quinn et al., 2015).

Switchgrass is characterized by low nutrient requirement. Bullard and Metcalfe (2001) think that NPK fertilization should be used at the stage of plantation establishment and the fertilizer rates proposed by them are as follows: $80 \mathrm{~kg} \mathrm{NH}_{4} \mathrm{NO}_{3}$ $\left(28 \mathrm{~kg} \mathrm{~N} \cdot \mathrm{ha}^{-1}\right), 40 \mathrm{~kg} \mathrm{P} \mathrm{P}_{5}\left(17.5 \mathrm{~kg} \mathrm{P} \cdot \mathrm{ha}^{-1}\right)$, and $60 \mathrm{~kg} \mathrm{~K} \mathrm{~K}_{2} \mathrm{O}\left(49.8 \mathrm{~kg} \mathrm{~K} \cdot \mathrm{ha}^{-1}\right)$. Sokhansanj et al. (2009) as well as Christensen and Koppenjan (2010) claim that in the first year of plantation nitrogen fertilizers are not recommended to be applied because weeds characterized by higher biomass increase could suppress the slowly growing young seedlings of switchgrass. Over the plantation lifetime, nitrogen fertilizers are applied to increase biomass yield, but the need to use phosphorus and potassium is determined by the content of these nutrients in the soil (Sanderson et al., 1996; McLaughlin et al., 2002). Nitrogen fertilization also has a beneficial effect on the content of lignin in biomass (Withers, 2010). According to Samson (2007), nitrogen fertilization at a rate of $50-60 \mathrm{~kg} \mathrm{~N} \cdot \mathrm{ha}^{-1}$ is appropriate to obtain optimal biomass production in switchgrass, whereas higher rates may reduce its yield. The nitrogen rate that will positively affect switchgrass yield depends on many factors, among others, climatic conditions and the productivity of switchgrass cultivars (An et al., 2018). Thus, in some studies yields have been observed to increase at higher nitrogen rates than those applied by Samson (2007). For example, based on the literature data Gunderson et al. (2008) report that lowland and upland ecotypes reach the maximum yield under nitrogen fertilization at rates of 90 and $100 \mathrm{~kg} \cdot \mathrm{ha}^{-1}$, respectively. Kering et al. (2012), Giannoulis et al. (2016) and Alexopoulou et al. (2017), on the other hand, observed an 
increase in switchgrass biomass production at a nitrogen doses of $135 \mathrm{~kg} \cdot \mathrm{ha}^{-1}$ and 80 , $160,240 \mathrm{~kg} \cdot \mathrm{ha}^{-1}$ and $75,150 \mathrm{~kg} \cdot \mathrm{ha}^{-1}$, respectively. Nitrogen rate should be adjusted depending on the level of this nutrient in the soil (Mitchell et al., 2014). In planning nitrogen fertilization, biomass harvest date should also be taken into account (Miesel et al., 2017). If harvest is to be carried out after the end of the growing season (the first ground frost), the applied nitrogen rate should be lower than in the case of an earlier harvest date (Mitchell et al., 2016). Generally, moderate nitrogen rates under particular soil conditions are entirely sufficient and allow high switchgrass yields to be obtained (Thomason et al., 2004).

Switchgrass is characterized by efficient use of both potassium and phosphorus. Information can be found in the literature which shows that these two elements have effect on biomass yield quantity and quality but also information which proves that they can do not affect the yield of switchgrass. The effect of using $\mathrm{K}$ and $\mathrm{P}$ fertilizers on the yield of switchgrass depends on the content of these macroelements in the soil. In general, on soils with a deficiency of $\mathrm{N}$ and $\mathrm{P}$, switchgrass reacts positively to fertilization of $\mathrm{K}$ or P. However, this beneficial effect is not observed on soils that are rich in K and P (Muir et al., 2001; Kering et al., 2012; Shield et al., 2012; Kering et al., 2013). Some studies indicate that the use of multi-ingredient fertilizer increases the yield of switchgrass. Ameen et al. (2018) showed that the fertilizer mixture of N, P, and $\mathrm{K}$ (NPK) caused increase in biomass yield of switchgrass compared with the PK, NK, and NP treatments. Mohammed et al. (2015) showed that mixture fertilizer NPK significantly increased biomass yield of switchgrass (by 49\%) compared to the control treatment. In turn, calcium fertilizers should only be used when the soil $\mathrm{pH}$ is below 5 (Bates et al., 2008).

Good results were obtained using organic cattle manure (CM) and poultry litter (PL) fertilizers on the switchgrass. It was found that these fertilizers increased biomass yield significantly to the extent of 30 and $23 \%$ compared with combined chemical fertilizer (12.9 $\mathrm{Mg} \cdot \mathrm{ha}^{-1}$ ) (Mohammed et al., 2015).

\section{Biomass yield and harvest}

In the first and second year of cultivation, biomass productivity reaches from 33 to $66 \%$ of the maximum production level (McLaughlin and Kszos, 2005). It is only in the 3 rd year of plant growth that the biomass production reaches $100 \%$ productivity on light soils, whereas on heavy soils this occurs 2-3 years later. Due to this, in the first year switchgrass is usually not harvested, nor is animal grazing recommended, in particular in plantations established in a cooler climate (Christensen and Koppenjan, 2010). From the year in which the optimal productivity is reached, in properly managed switchgrass plantations yields can be maintained at a constant high level for more than 10 next years (Mitchell et al., 2008, 2016; Monti et al., 2009a; Sokhansanj et al., 2009).

The annual switchgrass yield is from several to over a dozen $\mathrm{Mg}$ of dry matter (DM) per hectare, though it may exceed $20 \mathrm{Mg} \mathrm{DM} \cdot \mathrm{ha}^{-1}$ and even more than $30 \mathrm{Mg} \mathrm{DM} \cdot \mathrm{ha}^{-1}$, depending on environmental and agronomic factors as well as the cultivar, ecotype and plantation age (Gunderson et al., 2008; Smeets et al., 2009; Hattori and Morita, 2010). Generally, lowland species are characterized by higher yields than upland cultivars. A review of literature data by Heaton et al. (2004) shows that the average annual yield is $10 \mathrm{Mg} \mathrm{DM} \cdot \mathrm{ha}^{-1}$. In Poland, the average yield of switchgrass grown on a light soil in the area of Wrocław in the period 2004-2006 was 7.16 Mg DM· ha ${ }^{-1}$ (Dradrach et al., 2007). 
Switchgrass productivity is significantly dependent on the amount of rainfall during the growing season and is higher on well-irrigated soils (Kimura et al., 2015).

Harvest date and frequency depend on climatic and soil conditions, switchgrass ecotype and the future use of biomass harvested (Casler and Boeb, 2003; Jiang et al., 2014). Potentially, switchgrass can be harvested once or several times during the growing season or once after the end of the growing season. In the case of several harvests, a larger amount of nutrients, in particular nitrogen, is removed with the yield (Prieto et al., 2017; Wang et al., 2018). For this reason, plantation operating costs increase due to the need to replenish soil nitrogen at higher nitrogen fertilizer rates. Moreover, each successive harvest requires equipment for biomass cutting and transport, which generates additional economic costs (Christensen and Koppenjan, 2010). A single harvest during the growing season (e.g. in the middle of August or at the turn of summer and autumn) allows a high biomass yield to be obtained (Vogel et al., 2002; Lemus et al., 2008). A late autumn harvest gives a relatively high yield, but the productivity can be lower by 10-20\% compared to an earlier harvest (Vogel et al., 2002). But a frequent harvest adversely affects the condition of plants and plantation longevity (Fike et al., 2006; Lee et al., 2014b). It should be stressed that after the end of the growing season nutrients from the aboveground parts of switchgrass plants are transported to the roots (Anderson et al., 2013; Lindsey et al., 2013; Wayman et al., 2014). That is why a single harvest after the end of the growing season is more appropriate in the context of good overwintering of the rhizome (following Mitchell and Schmer, 2012). A spring harvest (before plant growth begins) causes the lowest losses in reserve nutrients (Adler et al., 2006; Samson, 2007; Guretzky et al., 2011; Gamble et al., 2015), but the yield harvested during this period is lower than the yield obtained from an autumn harvest (Adler et al., 2006; Cherney et al., 2018). Yield losses result, among others, from dry and brittle leaves of switchgrass plants being blown away by strong winds. Most frequently, the harvest is carried out once a year, though in the case of upland ecotypes grown in a warmer climate a high yield is also obtained with two biomass harvests per year (Fike et al., 2006).

The harvest is carried out using one-stage technology (simultaneous cutting and grounding) or two-stage technology (first the cutting operation, then grounding). It should be indicated that the grounding operation is important when switchgrass biomass is used for energy purposes. In the case of biomass to be burned or subjected to thermochemical conversion, low moisture, ash, nitrogen, potassium and chlorine contents are also of major importance (Lindsey et al., 2013; Liu et al., 2014; Sadeghpour et al., 2014a; Gorlitsky et al., 2015). It is essential that the values of these parameters are lowest in spring-harvested biomass (Table 2) (Adler et al., 2006; Zegada-Lizarazu et al., 2010; Lee et al., 2014b; Cherney et al., 2018). During the summer period, the plant water content is about $70 \%$, at the end of autumn it decreases to about $40 \%$ (following Sokhansanj et al., 2009), while in spring-harvested biomass it can be from several to over a dozen percent (Adler et al., 2006; Samson, 2007; Sadeghpour et al., 2014a). It is worth mentioning that a low plant water content facilitates harvest as well as storage and pelletization of the material harvested. But biomass with a water content of $>20 \%$ can be stored only for a short time and its drying is costly (Sokhansanj et al., 2009). Harvest at a later time seems to be less favorable when the biomass will be subjected to enzymatic hydrolysis (bioethanol production) because the biomass harvested during this time contains more lignin which hinders this 
process (Lindsey et al., 2013; Aurangzaib et al., 2016; Serapiglia et al., 2017). However, this component increases the energy value of biomass (Williams et al., 2016).

Table 2. The ash and selected elements content in switchgrass depending on the harvest date. (Adler et al., 2006)

\begin{tabular}{c|c|c|c|c}
\hline \multirow{2}{*}{ Harvest date } & Ash & N & K & Cl \\
\cline { 2 - 5 } & \multicolumn{4}{|c}{ \% dry matter } \\
\cline { 2 - 5 } & \multicolumn{4}{|c}{ Experience plots } \\
\hline Autumn & 3.41 & 0.62 & 0.33 & 0.10 \\
Spring & 2.47 & 0.54 & 0.06 & 0.03 \\
\hline & \multicolumn{4}{|c}{ Experience canopy } \\
\hline Autumn & 3.46 & 0.43 & 0.34 & 0.06 \\
Spring & 2.26 & 0.40 & 0.07 & 0.01 \\
\hline
\end{tabular}

Switchgrass is harvested using conventional farming equipment. It is mowed at a height of 10-15 cm from soil surface and the cut biomass is baled into round or rectangular bales that are stored in a dry place isolated from the ground. To reduce storage losses, biomass with a moisture content $>18 \%$ should be field dried before it is baled (Garland, 2008; Monti et al., 2009b; following Mitchell and Schmer, 2012).

\section{The use of biomass for energy purposes}

The growing problem of greenhouse emissions and the increasing demand for energy have enhanced the interest in energy sources alternative to fossil fuels. Biomass is an appropriate energy source that can provide in a short time transportation fuels such as biodiesel and bioethanol. Bioethanol is one of the most known biofuels that can be a substitute for petrol (Alvira et al., 2010). The possibility of using first generation bioethanol, produced from maize, wheat, sugar beet, sugar cane, etc., has been studied thus far (Bai et al., 2010). Nevertheless, the production of biofuels from food raw materials arouses a lot of controversy and therefore second-generation biofuels are used, which are produced from lignocellulosic substrates (e.g. switchgrass, straw). Switchgrass biomass can be converted to useful energy by direct combustion or during the production of liquid (bioethanol) and gaseous biofuels (syngas, biogas) (Sanderson et al., 2006; Alvira et al., 2010; Schmer et al., 2014).

\section{Combustion and co-firing of switchgrass}

Switchgrass biomass can be used in the burning process as a stand-alone fuel or can be co-fired with coal. However, the use of switchgrass as the only source of fuel or in a mixture with coal in high capacity power plants is not common or economically beneficial. This is due to slagging and contamination of the combustion systems (Karlsson et al., 2015). The reason for this adverse phenomenon is the presence of potassium, calcium, magnesium, chlorine and silicon in biomass in amounts larger than in coal (Qin et al., 2006; Antunes and de Oliveira, 2013). The higher the potassium and sodium content, the lower the biomass ash melting point and as a result of this the greater the slagging and the boiler corrosion. Gaseous chlorine and hydrogen chloride are the main corrosion factors of power boilers, but the action of $\mathrm{HCl}$ on boiler metal 
jest less dangerous than that of $\mathrm{Cl}_{2}$. Chlorides, especially potassium and sodium chlorides, released during biomass burning condense on the surface of the boilers and superheater tubes. Then, in a reaction of the chlorides with iron oxides present in the deposits or $\mathrm{SO}_{2}$ that occurs in flue gas, chlorine and hydrogen chloride are formed, respectively. The solid products of these reactions, on the other hand, are melted into a glassy viscous layer that captures non-volatile elements ( $\mathrm{Ca}, \mathrm{Si}$ and $\mathrm{Mg}$ ) from which silicates are formed with lower melting points than in the case of chlorides, which increases the risk of corrosion (Hardy et al., 2009; Kumar et al., 2017).

The effectiveness of switchgrass biomass burning is also dependent on ash and moisture content. The composition and calorific value of switchgrass are shown in Table 3. A relatively high ash content in switchgrass is due to the higher proportion of leaves, which can contain 3 times more ash than the stems, in the biomass of this plant (Table 4) (Madakadze et al., 1999; Hu et al., 2010; Vamvuka et al., 2010). Ash reduces the calorific value of biomass. A high moisture content of biomass also results in a reduced calorific value and this content should not be more than 23\% (Lewandowski and Kicherer, 1997). In the biomass burning process, nitrogen content is also important, since it affects $\mathrm{NO}_{\mathrm{x}}$ emissions (Elbersen, 2001). According to Lewandowski and Kicherer (1997), the nitrogen content in dry matter should be $<10 \mathrm{~g} \cdot \mathrm{kg}^{-1} \mathrm{DM}$ (dry matter).

Table 3. The composition and calorific value of the biomass of switchgrass

\begin{tabular}{c|c|c|c|c|c|c|c}
\hline $\begin{array}{c}\mathbf{C} \\
(\% \mathbf{D M})\end{array}$ & $\begin{array}{c}\mathbf{H} \\
(\boldsymbol{\%} \mathbf{D M})\end{array}$ & $\begin{array}{c}\mathbf{N} \\
(\boldsymbol{\%} \mathbf{D M})\end{array}$ & $\begin{array}{c}\mathbf{O} \\
(\boldsymbol{\%} \mathbf{D M})\end{array}$ & $\begin{array}{c}\text { Ash } \\
(\boldsymbol{\%} \mathbf{D M})\end{array}$ & $\begin{array}{c}\text { Moisture } \\
(\boldsymbol{\%})\end{array}$ & $\begin{array}{c}\text { High Heating } \\
\mathbf{V a l u e , ~ H H V} \\
\left(\mathbf{M J} \cdot \mathbf{k g}^{-1} \mathbf{D M}\right)\end{array}$ & Source \\
\hline 44.5 & 5.8 & 0.5 & 45.7 & 3.7 & 6.2 & 19.5 & $\begin{array}{c}\text { (Pilon and } \\
\text { Lavoie, 2011) } \\
(\text { Tillman, 2000; } \\
\text { ECN, 2016) }\end{array}$ \\
\hline
\end{tabular}

DM - dry matter

Table 4. Percentage of internodes, nodes, and leaves of switchgrass in the dry mass. (Hu et al., 2010)

\begin{tabular}{c|c|c|c}
\hline Variety & Internodes (\%) & Nodes (\%) & Leaves (\%) \\
\hline Alamo & 26.8 & 3.7 & 69.5 \\
Kanlow & 25.9 & 3.2 & 71.0 \\
\hline
\end{tabular}

Research shows that burning switchgrass biomass mixed with coal can bring ecological benefits, such as reduced emissions of some atmospheric pollutants and an increase in biomass heating rate during this process (Kumar et al., 2017). Switchgrass and coal can be co-fired in pulverized coal-fired boilers (which are commonly used in Polish power plants and combined heat and power plants) as well as in fluidized beds. Co-firing in pulverized coal-fired boilers requires the biomass to be converted into a homogeneous material with a grindability similar to that of coal. This is due to the fact that the co-firing process is preceded by biofuel grinding in coal mills, which are structurally unsuitable for co-milling of coal with raw biomass (Zuwała et al., 2014). During the combustion of a coal and biomass mixture in fluidized beds, on the other 
hand, pollutants are deposited on the coils of the secondary superheaters of the boiler which hinder its operation (Hycnar, 2006). It should be added that the risk of chloride corrosion in the co-firing process is not high if the percentage of biomass in the fuel stream does not exceed 10\% (Hardy et al., 2009).

\section{Bioethanol production from switchgrass}

Switchgrass is considered a good substrate to produce bioethanol because of its biomass yield, high carbohydrate content, good adaptation to various soil and climate conditions, and low agricultural requirements for its production. Preferred ecotypes for bioenergy applications is lowland ecotypes. This is due to the fact that the biomass yield is higher compared to lowland ecotypes (Dien et al., 2013). In studies Dien et al. (2013) the higher content of carbohydrate occurred in upland ecotype and increased with harvest maturity.

The process of bioethanol production is based on the fermentation of monosaccharides (pentoses and hexoses) that are formed as a result of enzymatic hydrolysis of the polysaccharides (cellulose and hemicelluloses) contained in switchgrass biomass. Cellulose and hemicelluloses, together with lignin, are the major components of the lignocellulose polymer which is not very susceptible to enzymatic hydrolysis due to its complex structure (Lee et al., 2014a; Williams et al., 2016; Zabed et al., 2017). In the lignocellulosic complex, lignin is the most difficult to hydrolyze, mainly due to the presence of carbon-carbon bonds and ether-type bonds in its structure, while the hemicelluloses are relatively easiest to hydrolyze. Moreover, the lignin and hemicelluloses surrounding the microfibers of the cellulose effectively impede the degradation of this polysaccharide by the cellulosic enzymes (Waramit et al., 2011; Umezawa, 2018).

Individual varieties of switchgrass differ in the content of carbohydrates and their individual fractions. Studies on biomass composition of five switchgrass genotypes, selected from twenty-two as the best yielding, were carried out by Min et al. (2017). Biomass composition was analyzed for total carbohydrate polymers (glucan + xylan + arabinan), total lignin (acid-soluble lignin + acid-insoluble lignin) and total extractives (water-soluble extractives + ethanol-soluble extractives) contents. The SWG 2007-2 genotype switchgrass had the highest amount of total carbohydrate polymers and the lowest amount of total lignin; therefore, this genotype is the most promising switchgrass line for the bioconversion to produce biofuel through sugar platform route. On the other hand high ratio of [water soluble carbohydrates + starch + cellulose]:hemicellulose showed that biomass of switchgrass stems and whole aboveground part (2.39 and 2.40) could be highly valuable feedstock for liquid biofuel production (Butkute et al., 2013).

Thus, to reduce the resistance of lignocellulose and its fractions (in particular cellulose and lignin) to enzymatic action, the biomass structure and chemical composition should be changed (Rijal et al., 2012). These effects can be achieved through biomass pretreatment using the following methods: mechanical (grinding, milling), chemical (decomposition using acids $\left(\mathrm{H}_{2} \mathrm{SO}_{4}, \mathrm{HCl}\right)$ and bases $(\mathrm{NaOH}, \mathrm{KOH}$, $\left.\mathrm{Ca}(\mathrm{OH})_{2}\right)$ as well as ammonium and ozone), thermal (in which steam heating, for example, is used), and also biological (the use of microorganisms to degrade or digest the cellulose and lignin) (Xu et al., 2011; Larsen et al., 2012; Karp et al., 2015; Loow et al., 2016; Sharma et al., 2016; Chen et al., 2018; Rajendran et al., 2018). Acid hydrolysis or base hydrolysis is relatively cheap and commonly used methods of 
chemical biomass pretreatment. The study of Rijal et al. (2012) showed the beneficial effect of acid or base pretreatment as well as of grinding and heating in a pellet mill on the efficiency of enzymatic hydrolysis of switchgrass biomass.

The process that follows pretreatment is enzymatic hydrolysis designed to convert the cellulose and hemicelluloses to fermenting sugars, which include glucose and xylose. This method uses the complexes of three enzymes (cellulases and hemicellulases) which are produced by microorganisms and which have a synergistic effect during the hydrolysis of cellulose (endo- $\beta$-1,4-glucanases, exo- $\beta$-1,4-glucanases, and $\beta$-glucosidase) and hemicelluloses (endo- $\beta$-1,4-xylanases, exo- $\beta-1,4$-xylanases and $\beta$-xylosidase). These polysaccharides are hydrolyzed to monosaccharides. The glucose derived from the hydrolysis is usually subjected to fermentation using strains of the yeast Saccharomyces cerevisiae and the bacterium Zymomonas mobilis. But xylose is converted by other yeasts, such as Pachysolen tannophilus, Candida shehatae, and Pichia stipitis (following Zabed et al., 2017). However, problems have been noted with the use of xylose-fermenting yeasts due to their low tolerance to ethanol, slow fermentation rate and difficulties with adjusting the reaction conditions (Keshwani and Cheng, 2009). Therefore, strains of bacteria such as Escherichia coli and Zymomonas mobilis have been modified in recent years using genetic engineering. Nevertheless, the fermentation capacity of these strains is not sufficiently effective. Genetically modified strains of Sacharomyces cerevisiae are currently used in the process of biomass conversion to ethanol, which is common for xylose and glucose (Balan et al., 2012).

The results of studies on the efficiency of ethanol from switchgrass biomass, with reference to other biomass resources, using in process Sachcaromyces cerevisiae are presented by Guragain et al. (2014) (Table 5).

Table 5. Ethanol production at shake flask level using fermentation of biomass hydrolyzed using S. cerevisiae. (Guragain et al., 2014)

\begin{tabular}{c|c|c|c|c}
\hline Type of biomass & $\begin{array}{c}\text { Ethanol yield } \\
\left(\mathbf{g}^{-\mathbf{1}} \mathbf{g l u c o s e}\right. \\
\mathbf{c o n s u m e d})\end{array}$ & $\begin{array}{c}\text { Productivity } \\
\left(\mathbf{g} \cdot \mathbf{l}^{-\mathbf{1}} \cdot \mathbf{h}^{-\mathbf{1}} \mathbf{)}\right.\end{array}$ & $\begin{array}{c}\text { Ethanol yield } \\
\left(\mathbf{g} \cdot \mathbf{g}^{-\mathbf{1}} \mathbf{\text { pretreated }}\right. \\
\mathbf{b i o m a s s})\end{array}$ & $\begin{array}{c}\text { Ethanol yield } \\
\left(\mathbf{g} \cdot \mathbf{g}^{-\mathbf{1}} \mathbf{\text { raw }}\right. \\
\text { biomass })\end{array}$ \\
\hline Switchgrass & $0.492 \pm 0.003$ & $2.17 \pm 0.039$ & $0.16 \pm 0.0029$ & $0.10 \pm 0.003$ \\
Wheat straw & $0.492 \pm 0.003$ & $2.87 \pm 0.003$ & $0.22 \pm 0.0002$ & $0.12 \pm 0.003$ \\
Miscanthus & $0.489 \pm 0.007$ & $2.27 \pm 0.030$ & $0.17 \pm 0.0022$ & $0.10 \pm 0.001$ \\
Sorghum bagasse & $0.494 \pm 0.005$ & $2.80 \pm 0.081$ & $0.21 \pm 0.0061$ & $0.13 \pm 0.003$ \\
\hline
\end{tabular}

Productivity was measured for $15 \mathrm{~h}$ of fermentation at $30{ }^{\circ} \mathrm{C}$ and expressed as gram of ethanol produced per liter per hour

The yeast Saccharomyces cerevisieae only ferment hexoses and are not able to use pentoses contained in biomass. Therefore, other microorganisms that do not have this negative trait are used for the fermentation of sugars and are competitive to $S$. cerevisa strains in terms of the amount of ethanol produced (Kurylenko et al., 2014). Abdullahi et al. (2017) studied the effect of $\mathrm{N}$ fertilization and acidic switchgrass biomass hydrolysis on ethanol yield. Pre-treatment was carried out with $\mathrm{HCl}$ (concentrations of 3, 4 and 5\%). Saccharomyces cerevisiae and Gram-negative Zymomonas mobilis were used in the fermentation process. The microorganisms were used singly and in combination. The beneficial effects of nitrogen doses of 50 and $75 \mathrm{~kg} \mathrm{~N} \cdot \mathrm{ha}^{-1}$ and treatment with $4 \%$ acid on the content of reducing sugars in the hydrolyzate were found. 
The most ethanol was obtained when the hydrolyzate was fermented using the combination of Saccharomyces cerevisiae and Zymomonas mobilis.

Hydrothermal pretreatment is recommended for grass biomass (Alvira et al., 2010; Kim et al., 2011). As a result of the hydrothermal degradation of lignocellulosic biomass, liquid and solid fractions containing useful bioproducts of the depolymerisation of complex sugars can be obtained. Kim et al. (2011) showed that the content of glucose and xylose in switchgrass biomass processed by hydrothermolysis was higher than after the following pre-treatment methods: AFEX (ammonia fiber exolosion), SAA (soaking aqueous ammonia), lime and dilute sulfuric acid. According to Suryawati et al. (2009) temperature $200{ }^{\circ} \mathrm{C}$ and time $10 \mathrm{~min}$ are the best conditions for the hydrothermolysis of switchgrass. Under these conditions, Suryawati et al. (2008) reported an increase in glucan content from 36.6 to $56.6 \%$ (dry basis) and a reduction in the xylan content from 21.0 to $2.4 \%$ (dry basis) in the solid fraction of switchgrass.

The most problematic step in the biochemical method of obtaining ethanol is the hydrolysis. It is related to the fact that simple sugars which are the end products of enzymatic hydrolysis inhibit the activity of enzymes: cellulases and hemicellulases. For complete hydrolysis of lignocellulose polysaccharides, the sugars released should be directly (in the same tank) transformed by fermenting organisms into ethanol. It is possible in the process of simultaneous saccharification and fermentation (SSF process) (Kurylenko et al., 2014). Faga et al. (2010) conducted research on fermentation of switchgrass biomass using the SSF process. For the pretreatment of biomass, hydrothermolysis (water in the subcritical state, temperature $200{ }^{\circ} \mathrm{C}$, holding time $10 \mathrm{~min}, 10 \%(\mathrm{w} / \mathrm{w})$ solids loading) was applied. The following yeast strains were used for the fermentation: Kluyveromyces marxianus IMB 1, IMB 2, IMB 3, IMB 4 and IMB 5 (culture at $45{ }^{\circ} \mathrm{C}$ ) and Saccharomyces cerevisiae $\mathrm{D}_{5} \mathrm{~A}$ (culture at $37{ }^{\circ} \mathrm{C}$ ). The fermentation process was carried out for: $72 \mathrm{~h}$ (K. marxianus IMB 1, IMB 2, IMB 4 and IMB 5), $96 \mathrm{~h}$ (K. marxianus IMB 3) and 7 days (S. cerevisiae $\left.\mathrm{D}_{5} \mathrm{~A}\right)$. The effect of buffer $\mathrm{pH}$ on bioethanol production by $S$. cerevisiae $\mathrm{D}_{5} \mathrm{~A}$ was also investigated. It was found that in 96 and $120 \mathrm{~h}$ of fermentation, the strains IMB 3 and S. cerevisiae $\mathrm{D}_{5} \mathrm{~A}$ were characterized by a higher yield of ethanol production in relation to other $K$. marxianus strains. In the final fermentation stage, the bioethanol production efficiency for IMB 3, IMB 1, IMB 5 strains was at a similar level, but lower than for IMB 3 and S. cerevisiae. With the lowering of the $\mathrm{pH}$ from 5.5 to 4.8, reduction of ethanol production by $S$. cerevisiae $\mathrm{D}_{5} \mathrm{~A}$ was observed. Research Sykes et al. (2016) indicate that ethanol efficiency method is significantly reduced by the use of biomass switchgrass infected with rust.

Bioethanol from switchgrass biomass can also be obtained without pre-treatment, which reduces the costs of the process. Chung et al. (2014) proposed the use of a genetically modified strain of Caldicellulosiruptor bescii for fermentation. Genetic modification consisted of among others on the introduction of a gene responsible for coding the enzyme allowing ethanol synthesis. A gene isolated from Clostridium thermocellum was used for this purpose. The degree of biomass processing using the Caldicellulosiruptor bescii recombinant was about $30 \%$ and 1.7 moles of ethanol was obtained from each one mole of glucose. Fu et al. (2011) and Yee et al. (2014) studied the production efficiency of bioethanol from biomass of genetically modified switchgrass. Transgenic switchgrass was characterized by a decreased expression of the COMT (Caffeic acid O-methyltransferase) gene, which is responsible for the coding of one of the key enzymes in the lignin biosynthetic pathway. As a result, with the use of 
Clostridium thermocellum, a greater production of bioethanol from transgenic switchgrass biomass in relation to unmodified biomass was obtained.

Ethanol yield from switchgrass biomass from field-scale production ranged from about 2300 to $3500 \mathrm{~L} \cdot \mathrm{ha}^{-1}$ in depends on biomass yielding (Schmer et al., 2008). Net Energy Yield (NEY) of this biofuel ranged from 50 to more than $75 \mathrm{GJ} \cdot \mathrm{ha}^{-1}$. However the complex technological process of bioethanol production from lignocellulosic feedstocks involves significant costs. Moreover, the technology of producing liquid biofuels from this type of biomass has not been fully identified. In particular, the economic aspect is a barrier to the production of second generation biofuels being quickly spread. Energy inputs on the production and processing of switchgrass under the U.S. conditions are 50\% higher than the energy generated from the ethanol produced from this crop (Pimentel and Patzel, 2005).

\section{Conversion of switchgrass biomass to gaseous fuels}

In spite of the continuous development of bioethanol production from woody feedstocks, the reaction costs are still high, while the variation in biomass composition requires the selection of appropriate hydrolyzing enzymes. Thus, more practical and less costly possibilities of using biomass are sought. One of them is the production of gaseous fuels (Boateng et al., 2006).

Biomass-derived gaseous fuels can be obtained using various processes, including among others: thermal process (gasification and pyrolysis (Table 6)) and biochemical: anaerobic digestion. The former one is high-temperature conversion of biomass to gaseous fuels under the influence of a gasifying agent. On the other hand, pyrolysis is a process that does not require access of external oxidizing and reducing agents and hence can be a stand-alone process or one of the stages of gasification or combustion (Piechocki et al., 2010). The pyrolysis products are: non-condensable gases $\left(\mathrm{CO}, \mathrm{CO}_{2}\right.$, $\mathrm{CH}_{4}$, and $\mathrm{H}_{2}$ ), bio-oil (liquid) and bio-char (solid). Depending on the time of pyrolysis, the yield of these products varies. As a result of gasification synthesis gas (syngas) is produced, whose main components are as follows: $\mathrm{H}_{2}, \mathrm{~N}_{2}, \mathrm{H}_{2} \mathrm{O}, \mathrm{CH}_{4}, \mathrm{CO}$ and $\mathrm{CO}_{2}$. The amount and composition of the synthesis gas varies depending on the conditions of the gasification process (Damartzis and Zabaniotou, 2011; Sarkar et al., 2014). Lower heating value (LHV) of gases which produced in gasification and pyrolysis of switchgrass biomass are respectively: $4 \mathrm{MJ} \cdot \mathrm{Nm}^{-3}$ and $5.9 \mathrm{MJ} \cdot \mathrm{kg}^{-1}$ (Elbersen, 2001).

Table 6. Thermal conversion products of switchgrass biomass. (Elbersen, 2001)

\begin{tabular}{c|c|c}
\hline Product & Gasification & Pyrolysis \\
\hline $\mathrm{H}_{2}$ & $5 \%$ & - \\
$\mathrm{CH}_{4}$ & $3 \%$ & $5 \%$ \\
$\mathrm{CO}$ & $11 \%$ & $32 \%$ \\
Other & tar & Bio-oil, charcoal \\
\hline
\end{tabular}

Pyrolysis can be carried out in a reactor equipped with a mechanism that provides the flow and simultaneous mixing of the feedstock (e.g. a rotating drum reactor or a screw reactor). The syngas production efficiency is higher and the quality of syngas is better when biomass harvested at later dates is pyrolyzed (Boateng et al., 2006). Subsequently, 
through catalytic conversion bioethanol can be obtained from the synthetic gas derived using this method.

In studies by Boateng et al. (2007) with the use of a fluidized-bed reactor, the bio-oil efficiency was over $60 \%$ by mass and the energy conversion efficiency was in the range of $52 \%-81 \%$. He et al. (2009) studied the effect of feedstock moisture contents and pyrolysis temperature $(\mathrm{T})$ on the yield and physicochemical properties of the obtained bio-oil. It was shown that under conditions: moisture of $10 \%$ and $\mathrm{T}=450{ }^{\circ} \mathrm{C}$, moisture of $15 \%$ and $\mathrm{T}=550{ }^{\circ} \mathrm{C}$, the obtained bio-oils were characterized by the best physical properties. In addition, experience has shown that by modifying only two parameters of the pyrolysis process, it is possible to significantly affect the efficiency and properties of the obtained biofuel.

According to Boateng et al. (2007), Bridgeman et al. (2007) and He et al. (2009) the chemical composition of bio-oil made from switchgrass is dominated by oxygen compounds, mainly acids, alcohols, ketones, phenols and furans. The mentioned compounds and the presence of water give the hydrophilic character of bio-oil, which limits its useful properties. It should be noted that the water must be separated if the biooil is used to produce fuels (Imam and Capareda, 2012). The aqueous phase contained in bio-oil is attempted to be used for the production of hydrogen by means of microbial electrolysis (Borole and Mielenz, 2011). The presence in char and bio-oil of mainly derivatives of phenols, furans and cyclopentanones was also reported by Pilon and Lavoie (2013), who studied the switchgrass pyrolysis at temperatures 300, 400 and $500{ }^{\circ} \mathrm{C}$ and in the atmosphere of two different gases: $\mathrm{N}_{2}$ and $\mathrm{CO}_{2}$. The studies also showed the variability of biochar and bio-oil shares as well as their calorific value as a function of temperature and type of inert gas. In the process conducted at $500{ }^{\circ} \mathrm{C}$, less biochar was obtained than at temperatures of 300 and $400{ }^{\circ} \mathrm{C}$ in both $\mathrm{N}_{2}$ and $\mathrm{CO}_{2}$ environments. At $300{ }^{\circ} \mathrm{C}$ and in a $\mathrm{CO}_{2}$ atmosphere the char content was higher than at this temperature in the $\mathrm{N}_{2}$ environment. The calorific value of biochar at $300{ }^{\circ} \mathrm{C}$ and in the $\mathrm{CO}_{2}$ atmosphere showed a lower calorific value than at the same temperature under the $\mathrm{N}_{2}$ atmosphere ( 22.2 vs. $\left.24.5 \mathrm{MJ} \cdot \mathrm{kg}^{-1}\right)$. In turn, the calorific value of bio-oil at the temperature of 300 and $400{ }^{\circ} \mathrm{C}$ was similar in both atmospheres $\left(\sim 15 \mathrm{MJ} \cdot \mathrm{kg}^{-1}\right)$ and at a temperature of $500{ }^{\circ} \mathrm{C}$ it was higher in the atmosphere of $\mathrm{CO}_{2}$.

Research Mohamed et al. (2016) indicate that the use of catalysts in the pyrolysis process can improve the quality of bio-oil obtained from switchgrass biomass. The catalysts were used individually $\left(\mathrm{K}_{3} \mathrm{PO}_{4}\right.$; clinoptilolite; activated carbon) and in a mixture $\left(\mathrm{K}_{3} \mathrm{PO}_{4}+\right.$ clinoptilolite; $\mathrm{K}_{3} \mathrm{PO}_{4}+$ bentonite $)$. It was found that bio-oils obtained in the presence of catalysts $\left(\mathrm{K}_{3} \mathrm{PO}_{4}(10,20,30 \mathrm{wt} \%)\right.$, clinoptilolite (20 wt.\%), combinations $\left(10\right.$ wt. $\% \mathrm{~K}_{3} \mathrm{PO}_{4}+10$ wt. $\%$ clinoptilolite, 10 wt. $\% \mathrm{~K}_{3} \mathrm{PO}_{4}+10$ wt. $\%$ bentonite, 10 wt. $\% \mathrm{~K}_{3} \mathrm{PO}_{4}+10$ wt. $\%$ bentonite) were characterized by lower water content and viscosity in relation to bio-oil obtained without the use of catalyst. The presence of catalysts also positively influenced the quality parameters of biochar, including composition, surface area and porosity. The variability of bio-oil properties (including viscosity, $\mathrm{pH}$, calorific value) obtained from various tests makes it impossible to determine the appropriate quality standards, which in turn is a barrier to the use of this product on an industrial scale (He et al., 2009).

To gasify switchgrass biomass, fluidized bed boiler technology is most recommended, since fluidized bed boilers can use biofuels with a low volume density and a low ash melting point. In the process of switchgrass gasification using this technology, only light tar fractions are formed and boiler slagging does not occur. 
However, a disadvantage of this gasification method is the high carbon content in ash (Elbersen, 2001).

Methods of pretreatment of biomass, ie torrefaction and densification, may lead to obtaining syngas with better properties. Torrefaction is a high-temperature drying process in which a solid fuel (biocarbon) with improved properties towards the raw biomass is obtained. The basic methods of biomass densification are: briquetting and pelleting. Densification increases the volume density of biomass, which increases its usefulness for energy purposes. Sarkar et al. (2014) studied switchgrass biomass gasification, which was pre-treated with torrefaction (at 230 and $270{ }^{\circ} \mathrm{C}$ ), densification (pelleting) and combined treatment: torrefaction and densification. Gasification was carried out at 700, 800 and $900{ }^{\circ} \mathrm{C}$. The oxidizing agent was air. An increase in $\mathrm{H}_{2}$ and $\mathrm{CO}$ concentrations in the synthesis gas and its lower heating value (LHV) with increasing temperature was observed. The largest amounts of produced $\mathrm{H}_{2}\left(0.03 \mathrm{~kg} \cdot \mathrm{kg}^{-1}\right.$ biomass) and $\mathrm{CO}\left(0.72 \mathrm{~kg} \cdot \mathrm{kg}^{-1}\right.$ biomass) showed synthesis gas $\left(\mathrm{LHV}=5.08 \mathrm{MJ} \cdot \mathrm{m}^{-3}\right)$ obtained at $900{ }^{\circ} \mathrm{C}$. This gas came from biomass gasification, which was subjected to a combined treatment.

Research Pasangulapati et al. (2012) indicate that the content of cellulose, hemicellulose and lignin in the switchgrass biomass affects the quality of gas obtained as a result of thermal conversion. According to the authors, higher content of cellulose and hemicellulose in relation to lignins results in a higher proportion of $\mathrm{CO}$ and $\mathrm{CO}_{2}$ than $\mathrm{CH}_{4}$ in the produced gas. Switchgrass and wheat straw in comparison to other biomass tested (eastern red cedar and dry distilled grains with solubles (DDGS)) were characterized by the highest efficiency of coal conversion: 94 and 95\%, respectively. In the studies of Torreiero et al. (2018) biomass gasification process (Nicotiana glauca, Panicum virgatum, Elytrigia elongata) was tested. It was shown that the conversion efficiency of carbon from switchgrass biomass was the highest: $80 \%$ (oxidizing agent: air) and $91.3 \%$ (oxidizing agent: enriched air).

The syngas obtained from switchgrass biomass can be subjected to bacterial fermentation to produce bioethanol. For this purpose is best suited a syngas with a high content of carbon monoxide and hydrogen and small content of tar. Fermentation of syngas occurs with the use of anaerobic microorganisms, including from the genus Clostridium. According to Tanner (2008) the fermentation of syngas results in the production of $30 \%$ more bioethanol in relation to the biochemical conversion method using the same amount of biomass. Pardo-Planas et al. (2017) conducted simulation studies on the optimization of gasification of biomass with steam to a syngas rich in carbon monoxide and hydrogen. The paper analyzed the values of fuel-air equivalence ratio (ER) and molar ratio of steam to biomass (SBR) and the influence of their value on the quantity and percentage composition ( $\mathrm{CO}$ and $\mathrm{H}_{2}$ content) of the produced syngas. It was shown that in simulated conditions the efficiency of synthesis gas conversion to ethanol was $63.5 \%$. According to the authors, the hybrid method, ie the combination of gasification with fermentation, is a promising method for producing bioethanol from switchgrass biomass.

Qian et al. (2013) studied the effect of biomass type (switchgrass, sorghum straw and red cedar) and fuel-air equivalence ratio $\operatorname{ER}(0.20,0.25$ and 0.28$)$ on the physicochemical properties of char obtained as a result of gasification. It was shown that with the increase of the ER index, the following char parameters increased: Brunauer-Emmett-Teller (BET) surface area and ash content, while the content of moisture and fixed carbon decreased. 
Gaseous fuel from switchgrass biomass can be also obtained in the biochemical conversion process: anaerobic digestion (AD). In this process, microorganisms participate, which under anaerobic conditions convert organic substances of the raw material into biogas. The main components of biogas are: methane and carbon dioxide. The usefulness of switchgrass biomass for biogas production results from its chemical composition. Especially some of switchgrass germplasm could be of interest for biogas producers: biomass of octoploid switchgrass ecotype No. 64 by chemical composition was similar to that of reed canary grass, which is characterized by high energy potential (Butkute et al., 2013). It should be also noted that the solid fraction of post-fermentation residue can be used for the production of solid biofuels, which increases the energy and economic efficiency of the project (Czekała et al., 2018).

Anaerobic fermentation is a labile process whose normal course depends on many factors, including the content of lignins in the substrate. Lignins are resistant to biodegradation (hardly decomposed by methane bacteria) and therefore cause low methane production and reduce process efficiency. In order to use switchgrass biomass more efficiently for the synthesis of methane, pre-treatment is carried out by various methods: mechanical, chemical, thermal or biological (Rodriguez et al., 2017). These methods are similar to those used at the initial preparation stage for the production of bioethanol. Literature data demonstrate the effect of pre-treatment on the efficiency of methane production from switchgrass biomass (Frigon et al., 2012; Papa et al., 2015; Capecchi et al., 2016). Biological methods of pre-treatment, i.e. ensiling and the use of enzymes, are an alternative to physical and chemical methods due to the less onerousness for the environment. For the production of biogas to be possible throughout the year, the maintenance of switchgrass biomass is necessary. One of the treatments for the preservation of biomass is its ensiling (Bélanger et al., 2012). This process not only allows the biomass to be stored for a long period of time without loss, but also to ensure that physico-chemical composition remains unchanged during storage. The stability of the composition of switchgrass biomass is extremely important when it is used for the production of biogas (Herrmann et al., 2011). This composition, however, is altered due to side reactions, e.g. secondary fermentation, which may occur in the ensiling process. The production of silage is based on the metabolic processes of lactic acid bacteria. Therefore, in order to improve the stability of aerobic silage, it is recommended to use microbiological preparations containing strains of lactic acid bacteria. In view of the further use of ensiled biomass for the production of biogas, absolutely heterofermentative bacterial strains (eg, Lactobacillus buchneri, Lactobacillus brevis) are particularly useful (Liu et al., 2016). Under anaerobic conditions, the strains of these bacteria ferment simple sugars, both pentoses and hexoses, among others to lactic acid and acetic acid. Lactic acid is a biomass conservation factor in the ensiling process. Whereas, acetic acid is a component that methane bacteria use in the production of biomethane in methane fermentation. In order to obtain good quality silage, both bacterial and bacterial-enzymatic inoculum are used. Kupryś-Caruk (2017) investigated the effect of the addition of bacterial preparations Lactosil and 11CH4 on the quality of silage and biogas production, among others from switchgrass. Both preparations contained heterofermentative lactic acid bacteria and differed in the absence of homofermentative bacteria $(11 \mathrm{CH} 4)$. It was found that silages made with the addition of both Lactosil and $11 \mathrm{CH} 4$ were characterized by a higher content of lactic acid in relation to the control. The content of acetic acid was higher in silage with the addition of Lactosil, and the lower in silage with the preparation $11 \mathrm{CH} 4$ compared to silage 
made without the addition of these preparations. Significant more biogas was obtained from silage with the addition of $11 \mathrm{CH} 4$, which contained the least hemicelluloses and lignins. The problem of the effect of additives on the quality of silage and biogas yield was also investigated by Zhao et al. (2017). In the conducted experiment, the authors demonstrated a positive effect of the combined addition of the strain of Lactobacillus brevis and the xylanase enzyme on the volume of biogas production from switchgrass silage. The xylanase enzyme breaks down the lignocellulose hydrolytically into products that are used by the strain of Lactobacillus brevis. The use of this enzyme resulted in lowering the lignin content, which positively affected the quality of the obtained silage. Another way to optimize biogas production is to use mixed fermentation feeds, i.e. prepared on the basis of two types of substrates. One of the most common practices of this type is the mixing of plant biomass with manure. Due to the buffering properties of manure, the risk of lowering the $\mathrm{pH}$ in the fermenter and consequently stopping the fermentation process is reduced. Ahn et al. (2010) studied the effect of co-fermentation of manure with switchgrass silage on biogas yield in thermophilic conditions $\left(55^{\circ} \mathrm{C}\right)$. For mixture of switchgrass silage with swine manure, a $53 \%$ volatile solids reduction (VS) and a biogas yield of $0.373 \mathrm{~L} \mathrm{CH}_{4} \cdot \mathrm{g}^{-1} \mathrm{VS}$ were noted. However, for the other two mixtures (silage of switchgrass + dairy manure and silage of switchgrass + poultry manure) the reduction rates of VS and biogas yields were clearly lower: 9.3\%, $0.028 \mathrm{~L} \mathrm{CH}_{4} \cdot \mathrm{g}^{-1} \mathrm{VS}$ and $20 \%, 0.002 \mathrm{~L} \mathrm{CH}_{4} \cdot \mathrm{g}^{-1} \mathrm{VS}$, respectively. It should be noted that the higher share of ensiled biomass in the batch, the more acidification of the digester and the complete refraction of the process may occur. This is due to both the low $\mathrm{pH}$ of the silage and the production in the digester with the wrong composition and proportion of the substrate mixture of larger amounts of volatile fatty acids (VFA) (Thamsiriroj et al., 2012). In the studies of Ahn et al. (2010) high concentration of VFA was observed during fermentation of mixtures (silage of switchgrass + dairy manure and silage of switchgrass + poultry manure), which was maintained until the end of the process. The methane bacteria could not digest the accumulated acids, which led to acidification of the fermenter and a decrease in biomethane production capacity from these mixtures. For this reason, it is important to determine the right ratio of substrates used and to select the optimal initial loading of the digester with the charge of organic compounds. In addition, the content of dry matter in the digester, which has a significant influence on the yield of biogas, depends on the proportion of substrates in the mixture. Zheng et al. (2015) investigated the effect of various manure dairy farm to biomass relation to methane production in mesophilic conditions. The substrates were mixed in the following total solid ratios (TS): 4:0, 3:1, 2:2, 1:3 and 0:4. It was found that the co-digestion mixture with the ratio of $2: 2$ substrates showed the highest efficiency of methane production (158.6 $\left.\mathrm{mL} \mathrm{CH} \mathrm{CH}_{4} \cdot \mathrm{g}^{-1} \mathrm{VS}\right)$. In comparison to the monofermentation of manure and switchgrass, the increase in methane production was $74.5 \%$ and $18.3 \%$, respectively.

Among vegetable raw materials, maize is most commonly used in biogas installations. Research of Barbanti et al. (2014) shows that the production capacity of methane from switchgrass biomass is lower $\left(217 \mathrm{~mL} \mathrm{CH} \cdot \mathrm{g}^{-1} \mathrm{VS}\right)$ in relation to maize production (316 $\mathrm{mL} \mathrm{CH} \mathrm{CH}_{4} \cdot \mathrm{g}^{-1} \mathrm{VS}$ ). This is due to the higher content of structural carbohydrates and lignins in swtchgrass biomass in relation to maize biomass (Barbanti et al., 2014). The data provided in the literature also indicate differences in the production of biogas from switchgrass resulting from fluctuations in the composition and volume of its biomass yield. These characteristics are influenced by the variety, 
habitat and climate conditions of the crop and the applied agrotechnics. It seems therefore justified that varieties of switchgrass intended for biogas should be selected in terms of the same indicators as in the case of maize. These indicators include the highest possible dry matter content $\cdot \mathrm{ha}^{-1}$, low ash content, and lignin and the ability to ensilage (BiogasMagazine, 2012). Selection of varieties with the use of agrotechnics corresponding to local conditions and optimally selected parameters of methane fermentation should result in intensification of biogas production.

\section{Summary}

In the world, switchgrass is a species that is used more and more frequently for energy purposes. This species has many positive traits that make this plant very attractive and worthy of spreading. From the agricultural point of view, an enormous advantage of switchgrass is that it has low soil and fertilization requirements; switchgrass is also characterized by high resistance to diseases and pests and thereby it is relatively easy and cheap to grow. Moreover, it exhibits great durability and high biomass productivity over a long period of time and due to this it can be used in a given field for even 10 years without a significant decrease in yield. When switchgrass is used as an energy crop, it is possible to produce bioethanol, biogas (biomethane) and synthesis gas. Biomass of this species can also be co-fired with coal. The effectiveness of these processes is dependent on the moisture content, the ash content and composition as well as the lignin content in switchgrass biomass.

\section{REFERENCES}

[1] Abdullahi, A. A., Aliero, B. L., Aliero, A. A., Zuru, A. A., Rabah, A. B. (2017): Optimization of ethanol production from switchgrass (Panicum virgatum L.) grown in Sokoto geoecological zone of Nigeria. - International Journal of Chemistry, Pharmacy \& Technology 2(1): 43-56.

[2] Adkins, J., Jastrow, J. D., Morris, G. P., Six, J., de Graaff, M.-A. (2016): Effects of switchgrass cultivars and intraspecific differences in root structure on soil carbon inputs and accumulation. - Geoderma 262: 147-154.

[3] Adler, P. R., Sanderson, M. A., Boateng, A. A., Weimer, P. J., Jung, H. G. (2006): Biomass yield and biofuel quality of switchgrass harvested in fall or spring. - Agronomy Journal 98: 1518-1525.

[4] Ahn, H. K., Smith, M. C., Kondrad, S. L., White, J. W. (2010): Evaluation of biogas production potential by dry anaerobic digestion of switchgrass -animal manure mixtures. - Applied Biochemistry and Biotechnology 160: 965-975. DOI: 10.1007/s12010P009P8624Px.

[5] Alexopoulou, E., Zanettib, F., Papazoglouc, E. G., Christoua, M., Papatheoharic, Y., Tsiotasa, K., Papamichaela, I. (2017): Long-term studies on switchgrass grown on a marginal area in Greece under different varieties and nitrogen fertilization rates. Industrial Crops and Products 107: 446-452.

[6] Alvira, P., Tomás-Pejó, E., Ballesteros, M., Negro, M. J. (2010): Pretreatment Technologies for an effecient bioethanol production process based on enzymatic hydrolysis: A review. - Bioresource Technology 101: 4851-4861.

[7] Ameen, A., Tang, Ch., Han, L., Xie, G. H. (2018): Short-term response of switchgrass to nitrogen, phosphorus, and potassium on semiarid sandy wasteland managed for biofuel feedstock. - BioEnergy Research 11: 228-238. 
[8] An, Y., Gao, Y., Ma, Y. (2018): Growth performance and weed control effect in response to nitrogen supply for switchgrass after establishment in the semiarid environment. Field Crops Research 221: 175-181.

[9] Anderson, E. K., Parrish, A. S., Voigt, T. B., Owens, V. N., Hong, C.-H., Lee, D. K. (2013): Nitrogen fertility and harvest management of switchgrass for sustainable bioenergy feedstock production in Illinois. - Industrial Crops and Products 48: 19-27.

[10] Anderson, E. K., Hager, A. G., Voigt, T. B., Lee, D. K. (2014): Switchgrass and prairie cordgrass response to foliar- and soil-applied herbicides. - Weed Technology 28: 633645 .

[11] Antunes, R. A., de Oliveira, M. C. L. (2013): Corrosion in biomass combustion: A materials selection analysis and its interaction with corrosion mechanisms and mitigation strategies. - Corrosion Science 76: 6-26.

[12] Ashworth, A. J., Allen, F. L., Keyser, P. D., Tyler, D. D., Saxton, A. M., Taylor, A. M. (2015): Switchgrass yield and stand dynamics from legume intercropping based on seeding rate and harvest management. - Journal of Soil and Water Conservation 70: 374384. https://doi: 10.2489/jswc.70.6.374.

[13] Aurangzaib, M., Moore, K. J., Archontoulis, S. V., Heaton, E. A., Lenssen, A. W., Fei, S. (2016): Compositional differences among upland and lowland switchgrass ecotypes grown as a bioenergy feedstock crop. - Biomass and Bioenergy 87: 169-177.

[14] Bai, Y., Luo, L., van der Voet, E. (2010): Life cycle assessment of switchgrass-derived ethanol as transport fuel. - The International Journal of Life Cycle Assessment 15: 468477.

[15] Balan, V., Kumar, S., Bals, B., Chundawat, S., Jin, M., Dale, B. (2012): Biochemical and Thermochemical Conversion of Switchgrass to Biofuels. - In: Monti, A. (ed.) Switchgrass: A Valuable Biomass Crop for Energy. Springer-Verlag, London.

[16] Bals, B., Rogers, C., Jin, M., Balan, V., Dale, B. (2010): Evaluation of ammonia Fiber Expansion (AFEXTM) pretreatment for enzymatic hydrolysis of switchgrass harvested in different seasons and locations. - Biotechnology for Biofuels 3: 1-11.

[17] Barbanti, L., Di Girolamo, G., Grigatti, M., Bertin, L., Ciavatta, C. (2014): Anaerobic digestion of annual and multi-annual biomass crops. - Industrial Crops and Products 56: 137-144.

[18] Bates, G., Keyser, P., Harper, C., Waller, J. (2008): SP701-B-Using Switchgrass for Forage. The University of Tennessee Agricultural Extension Service, SP701B-5M3/08(Rep) R12-4110-070-012-08 08-0166, http://trace.tennessee.edu/utk_agexbiof/7 (accessed in May, 2018).

[19] Bélanger, G., Savoie, P., Parent, G., Claessens, A., Bertrand, A., Tremblay, G. F., Massé, D., Gilbert, Y., Babineau, D. (2012): Switchgrass silage for methane production as affected by date of harvest. - Canadian Journal of Plant Science 92: 1187-1197. https://doi.org/10.4141/cjps2011-202.

[20] BiogasMagazine https://www.deere.pl/pl_PL/docs/product/equipment/self_propelled_forage_harvester/Bio gas_Magazine.pdf. - Accessed in July, 2018.

[21] Boateng, A. A., Hicks, K. B., Vogel, K. P. (2006): Pyrolysis of switchgrass (Panicum virgatum L.) harvested at several stages of maturity. - Journal of Analytical and Applied Pyrolysis 75: 55-64.

[22] Boateng, A. A., Daugaard, D. E., Goldberg, N. M., Hicks, K. B. (2007): Bench-scale fluidized-bed pyrolysis of switchgrass for bio-oil production. - Industrial \& Engineering Chemistry Research 46(7): 1891-1897.

[23] Bocian, P., Golec, T., Rakowski, J. (2010): Modern Technologies of Biomass Production and Use for Energy Purposes. - BiOB, Warsaw (in Polish).

[24] Boe, A., Gagne, R. J. (2011): A new species of gall midge (Diptera: Cecidomyiidae) infesting switchgrass in the Northern Great Plains. - BioEnergy Research 4: 77-84. https://doi.org/10.1007/s12155-010-9102-6. 
[25] Borole, A. P., Mielenz, J. (2011): Estimating hydrogen production potential in biorefineries using 534 microbial electrolysis cell technology. - International Journal of Hydrogen Energy 36(22): 14787-14795.

[26] Boydston, R. A., Collins, H. P., Fransen, S. C. (2010): Response of three switchgrass (Panicum virgatum) cultivars to mesotrione, quinclorac, and pendimethalin. - Weed Technology 24: 336-341.

[27] Branson, D. H., Joern, A., Sword, G. A. (2006): Sustainable management of insect herbivores in grassland ecosystems: new perspectives in grasshopper control. Bioscience $\quad 56: \quad 743-755 . \quad$ https://doi.org/10.1641/00063568(2006)56[743:SMOIHI]2.0.CO;2.

[28] Bridgeman, T. G., Darvell, L. I., Jones, J. M., Williams, P. T., Bridgwater, A. V., Barraclough, T., Shield, I., Yates, N., Thain, S. C., Donnison, I. S. (2007): Influence of particle size on the analytical and chemical properties of two energy crops. - Fuel 86(12): 60-72.

[29] Bullard, M., Metcalfe, P. (2001): Estimating the Energy Requirements and $\mathrm{CO}_{2}$ Emissions from Production of the Perennial Grasses Miscanthus, Switchgrass and Reed Canary Grass. - ETSU B/U1/00645/REP. ADAS Consulting Ltd.

[30] Butkutè, B., Lemežienè, N., Cesevičienė, J., Liatukas, Ž., Dabkevičienė, G. (2013): Carbohydrate and lignin partitioning in switchgrass (Panicum virgatum L.) biomass as a bioenergy feedstock. - Zemdirbyste-Agriculture 100(3): 251-260.

[31] Capecchi, L., Galbe, M., Wallberg, O., Mattarelli, P., Barbanti, L. (2016): Combined ethanol and methane production from switchgrass (Panicum virgatum L.) impregnated with lime prior to steam explosion. - Biomass and Bioenergy 90: 22-31.

[32] Carris, L. M., Castlebury, L. A., Zale, J. (2008): First report of Tilletia pulcherrima bunt on switchgrass (Panicum virgatum) in Texas. - Plant Disease 92: 1707. https://doi.org/10.1094/PDIS-92-12-1707C.

[33] Casler, M. D. (2012): Switchgrass Breeding, Genetics, and Genomics. - In: Monti, A. (ed.) Switchgrass: A Valuable Biomass Crop for Energy. Springer-Verlag, London.

[34] Casler, M. D., Boeb, A. R. (2003): Cultivar $\times$ environment interactions in switchgrass. Crop Science 43: 2226-2233. https://doi:10.2135/cropsci2003.2226.

[35] Chen, B-C., Lai, H-Y., Juang, K-W. (2012): Model evaluation of plant metal content and biomass yield for the phytoextraction of heavy metals by switchgrass. - Ecotoxicology and Environmental Safety 80: 393-400.

[36] Chen, J., Adjallé, K., Barnabé, S., Perrier, M., Paris, J. (2018): Mechanical and thermal pretreatment processes for increasing sugar production from woody biomass via enzymatic hydrolysis. - Waste and Biomass Valorization 1-9. https://doi.org/10.1007/s12649-018-0217-x.

[37] Cherney, J. H., Cherney, D. J. R., Paddock, K. M. (2018): Biomass yield and composition of switchgrass bales on marginal land as influenced by harvest management scheme. BioEnergy Research 11: 33-43.

[38] Chojnacka, A., Romanowska-Duda, Z., Grzesik, M., Pszczółkowski, W., Sakowicz, T. (2010): Cyanobacteria as a Source of Bioactive Compounds for Crop Cultivation. - In: Wołowski, K., Kwandrans, J., Wojtal, A. Z. (eds.) Taxonomy the Queen of Science - The Beauty of Algae. Book of Abstracts of the 29th International Phycological Conference Kraków. Inst. Bot. Polish Acad. Sci., Krakow.

[39] Christian, D. G., Elbersen, H. W. (1998): Switchgrass (Panicum virgatum L.). - In: El Bassam, N. (ed.) Energy Plant Species: Their Use and Impact on Environment and Development. James \& James (Science Publishers) Ltd., London.

[40] Christensen, C. A., Koppenjan, G. (eds.). (2010): Planting and Managing Switchgrass as a Dedicated Energy Crop, 2nd ed. Blade Energy Crops. http://switchgrass.okstate.edu/other-information-

sources/Blade_Switchgrass_Crop_Guide_2009.pdf (accessed in May, 2018). 
[41] Chung, D., Cha, M., Guss, A. M., Westpheling, J. (2014): Direct conversion of plant biomass to ethanol by engineered Caldicellulosiruptor bescii. - Proceedings of the National Academy of Sciences 111(24): 8931. DOI: 10.1073/pnas.1402210111.

[42] Crouch, J. A., Beim, L. A., Cortese, L. M., Bonos, S. A., Clarke, B. B. (2010): Anthracnose disease of switchgrass caused by the novel fungal species Colletotricum navitas. $\quad-\quad$ Mycological Research 113: 1411-1421. https://doi.org/10.1016/j.mycres.2009.09.010.

[43] Czekała, W., Bartnikowska, S., Dach, J., Janczak, D., Smurzyńska, A., Kozłowski, K., Bugała, A., Lewicki, A., Cieślik, M., Typańska, D., Mazurkiewicz, J. (2018): The energy value and economic efficiency of solid biofuels produced from digestate and sawdust. Energy 159: 1118-1122.

[44] Damartzis, T., Zabaniotou, A. (2011): Thermo-chemical conversion of biomass to second generation bio-fuels through integrated process design - a review. - Renewable \& Sustainable Energy Reviews 15: 366-378.

[45] Dien, B. S., O’Bryan, P. J., Hector, R. E., Iten, L. B., Mitchell, R. B., Qureshi, N., Sarath, G., Vogel, K. P., Cotta, M. A. (2013): Conversion of switchgrass to ethanol using dilute ammonium hydroxide pretreatment: influence of ecotype and harvest maturity Environmental Technology 34(13-14): 1837-1848.

[46] Douglas, J., Lemunyon, J., Wynia, T., Salon, P. (2009): Technical Note No. 3. Planting and Managing Switchgrass as a Biomass Energy Crop. - USDA. NRCS. http://www.nrcs.usda.gov/Internet/FSE_DOCUMENTS/stelprdb1042293.pdf (accessed in May, 2018).

[47] Dradrach, A., Gąbka, D., Szlachta, J., Wolski, K. (2007): Energy value of several grass species cultivated on light soil. - Grassland Science in Poland 10: 29-35 (in Polish).

[48] Drinnon, D., McCord, J., Goddard, K., Walton, J., Ownley, B., Jackson, S., Rhodes, G. N., Tyler, D. (2014): Guidebook for the sustainable production practices of switchgrass in the southeastern U.S.

http://nativegrasses.utk.edu/publications/SustainableProductionPracticesSwitchgrass.pdf; http://www.se-ibss.org/publications-and-patents/extension-and-outreach-

publications/guidebook-for-the-sustainable-production-practices-of-switchgrass-in-thesoutheastern-u.s (accessed in July, 2018).

[49] Dudkiewicz, M., Bolibok, Ł. (2011): Selected energy plants as a landscaping element. Acta Scientiarum Polonorum, Formatio Circumiectus 10: 13-20 (in Polish).

[50] ECN (Energy Research Centre of the Netherlands). (2016): https://www.ecn.nl/phyllis2/Browse/Standard/ECN-Phyllis\#switchgrass. - Accessed in May, 2018.

[51] Elbersen, H. W. (ed.). (2001): Final Report FAIR 5-CT97-3701 "Switchgrass". Switchgrass (Panicum virgatum L.) as an alternative energy crop in Europe. Initiation of a productivity network. - https://subsites.wur.nl/en/switchgrass/Publications.htm (accessed in May, 2018).

[52] Elbersen, W., Poppens, R., Bakker, R. (2013): Switchgrass (Panicum virgatum L.). A perennial biomass grass for efficient production of feedstock for the biobased economy. https://subsites.wur.nl/en/switchgrass/Publications.htm (accessed in May, 2018).

[53] Evanylo, G. K., Abaye, A. O., Dundas, C., Zipper, C. E., Lemus, R., Sukkariyah, B., Rockett, J. (2005): Herbaceous vegetation productivity, persistence, and metals uptake on abiosolids-amended mine soil. - Journal of Environmental Quality 34: 1811-1819.

[54] Faga, B. A., Wilkins, M. R., Banat, I. M. (2010): Ethanol production through simultaneous saccharification and fermentation of switchgrass using Saccharomyces cerevisiae $\mathrm{D}_{5} \mathrm{~A}$ and thermotolerant Kluyveromyces marxianus IMB strains. - Bioresource Technology 101: 2273-2279.

[55] Fike, J. H., Parrish, D. J., Wolf, D. D., Balasko, J. A., Green, J. T., Rasnake, Jr. M., Reynolds, J. H. (2006): Switchgrass production for the upper southeastern USA: 
Influence of cultivar and cutting frequency on biomass yields. - Biomass and Bioenergy 30: 207-213.

[56] Frigon, J-C., Mehta, P., Guiot, S. R. (2012): Impact of mechanical, chemical and enzymatic pre-treatments on the methane yield from the anaerobic digestion of switchgrass. - Biomass and Bioenergy 36: 1-11.

[57] Fu, C., Mielenz, J. R., Xiao, X., Ge, Y., Hamilton, C. Y., Rodriguez, M., Chen, F., Foston, M., Ragauskas, A., Bouton, J., Dixon, R. A., Wang, Z.-Y. (2011): Genetic manipulation of lignin reduces recalcitrance and improves ethanol production from switchgrass. - Proceedings of the National Academy of Sciences 108(9): 3803-3808. http://www.pnas.org/cgi/doi/10.1073/pnas.1100310108 (accessed in July, 2018).

[58] Gamble, J. D., Jungers, J. M., Wyse, D. L., Johnson, G. A., Lamb, J. A., Sheaffer, C. C. (2015): Harvest date effects on biomass yield, moisture content, mineral concentration, and mineral export in switchgrass and native polycultures managed for bioenergy. BioEnergy Research 8: 740-749.

[59] Garland, C. D. (2008): Growing and harvesting switchgrass for ethanol production in Tennessee. $\quad$ Ext. Bull.

https://extension.tennessee.edu/publications/Pages/default.aspx (accessed in May, 2018) or http://utextension.tennessee. edu/publications/spfiles/SP701-A.pdf (accessed in May, 2018).

[60] Giannoulis, K. D., Karyotis, T., Sakellariou-Makrantonaki, M., Bastiaans, L., Struik, P. C., Danalatos, N. G. (2016): Switchgrass biomass partitioning and growth characteristics under different management practices. - NJAS - Wageningen Journal of Life Sciences 78: 61-67.

[61] Gołaszewski, J. (2011): The use of agricultural substrats in Polish biogas plants. Postępy Nauk Rolniczych 2: 64-94 (in Polish).

[62] Gorlitsky, L. E., Sadeghpour, A., Hashemi, M., Etemadi, F., Herbert, S. J. (2015): Biomass vs. quality tradeoffs for switchgrass in response to fall harvesting period. Industrial Crops and Products 63: 311-315.

[63] Gunderson, C. A., Davis, E. B., Jager, H. I., Perlack, R. D., West, T. O., Brandt, C. C., Wullschleger, S. D., Baskaran, L. M., Wilkerson, E. G., Downing, M. E. (2008): Exploring Potential U.S. Switchgrass Production for Lignocellulosic Ethanol. ORNL/TM-2007/183 National Laboratory Oak Ridge, Tennessee, USA. http://info.ornl.gov/sites/publications/files/Pub11922.pdf (accessed in May, 2018).

[64] Guragain, Y. N., Ganeshc, K. M., Bansala, S., Sathishc, R. S., Raoc, N., Vadlani, P. V. (2014): Low-lignin mutant biomass resources: Effect of compositional changes on ethanol yield. - Industrial Crops and Products 61: 1-8.

[65] Guretzky, J. A. Biermacher, J. T., Cook, B. J., Kering, M. K., Mosali, J. (2011): Switchgrass for forage and bioenergy: harvest and nitrogen rate effects on biomass yields and nutrient composition. - Plant Soil 339: 69-81.

[66] Gustafson, D. M., Boe, A., Jin, Y. (2003): Genetic variation for Puccinia emaculata infection in switchgrass. $\quad-$ Crop Science 43: 755-759. https://doi:10.2135/cropsci2003.7550.

[67] Hagan, A. K., Akridge, J. R. (2013): Efficacy of fungicides for the control of rust on switchgrass. - SNA Research Conference 58, Pathology and Nematology Section: 201204.

[68] Hanson, J. D., Johnson, H. A. (2005): Germination of switchgrass under various temperature and $\mathrm{pH}$ regimes. - Seed Technology 27: 2003-2010.

[69] Hardy, T., Kordylewski, W., Mościcki, K. (2009): Chlorine corrosion hazard due to firing and co-firing of biomass in boilers. - Archiwum Spalania 9: 181-195 (in Polish).

[70] Hattori, T., Morita, S. (2010): Energy crops for sustainable bioethanol production; which, where and how? - Plant Production Science 13: 221-234. 
[71] He, R., Ye, X. Ph., English, B. C., Satrio, J. A. (2009): Influence of pyrolysis condition on switchgrass bio-oil yield and physicochemical properties. - Bioresource Technology 100: 5305-5311.

[72] Heaton, E., Voigt, T., Long, S. P. (2004): A quantitative review comparing the yields of two candidate $\mathrm{C} 4$ perennial biomass crops in relation to nitrogen, temperature and water. - Biomass and Bioenergy 27: 21-30.

[73] Herrmann, C., Heiermann, M., Idler, C. (2011): Effects of ensiling, silage additives and storage period on methane formation of biogas crops. - Bioresource Technology 102(8): 5153-5161.

[74] Holguin, C. (2010): Insect diversity and pest status on switchgrass grown for biofuel in South Carolina. - All Theses. https://tigerprints.clemson.edu/all_theses/960 (accessed in July, 2018).

[75] Hu, Z., Sykes, R., Davis, M. F., Brummer, E. Ch., Ragauskas, A. J. (2010): Chemical profiles of switchgrass. - Bioresource Technology 101: 3253-3257.

[76] Hycnar, J. J. (2006): Fluidized beds - an example of rational solution of wastes problems. - Polityka Energetyczna 9: 365-376 (in Polish).

[77] Imam, T., Capareda, S. (2012): Characterization of bio-oil, syn-gas and bio-char from switchgrass pyrolysis at various temperatures. - Journal of Analytical and Applied Pyrolysis 93: 170-177.

[78] Jiang, Q. Z., Webb, S. L., Yesudas, C. R., Bhandari, H. S., Narasimhamoorthy, B., Bouton, J. H., Saha, M. C. (2014): Variance components and heritability of biomass yield in switchgrass (Panicum virgatum L.) grown in the Southern Great Plains. - Field Crops Research 168: 148-155. https://doi:10.1016/j.fcr.2014.07.016.

[79] Kabała, C., Karczewska, A., Kozak, M. (2010): Energetic plants in reclamation and management of degraded soils. - Zeszyty Naukowe Uniwersytetu Przyrodniczego we Wrocławiu Rolnictwo T.576(XCVI): 97-118 (in Polish).

[80] Karlsson, S., Âmand, L-E., Lisk, J. (2015): Reducing high-temperature corrosion on high-alloyed stainless steel superheaters by co-combustion of municipal sewage sludge in a fluidised bed boiler. - Fuel 139: 482-493.

[81] Karp, E. M., Resch, M. G., Donohoe, B. S., Ciesielski, P. N., O’Brien, M. H., Nill, J. E., Mittal, A., Biddy, M. J., Beckham, G. T. (2015): Alkaline pretreatment of switchgrass. ACS Sustainable Chemistry \& Engineering 3: 1479-1491.

[82] Kering, M. K., Biermacher, J. T., Butler, T. J., Mosali, J., Guretzky, J. A. (2012): Biomass Yield and Nutrient Responses of Switchgrass to Phosphorus Application. BioEnergy Research 5: 71-78.

[83] Kering, M. K., Butler, T. J., Biermacher, J. T., Mosali, J., Guretzky, J. A. (2013): Effect of potassium and nitrogen fertilizer on switchgrass productivity and nutrient removal rates under two harvest systems on a low potassium soil. - BioEnergy Research 6: 329335 .

[84] Keshwani, D. R., Cheng, J. J. (2009): Switchgrass for bioethanol and other value-added applications: A review. - Bioresource Technology 100: 1515-1523.

[85] Kibet, L., Blanco-Canqui, H., Mitchell, R. B., Schacht, W. H. (2016): Root biomass and soil carbon response to growing perennial grasses for bioenergy. - Energy, Sustainability and Society 6: 1-8.

[86] Kim, Y., Mosier, N. S., Ladisch, M. R., Pallapolu, V. R., Lee, Y. Y., Garlock, R., Balan, V., Dale, B. E., Donohoe, B. S., Vinzant, T. B., Elander, R. T., Falls, M., Sierra, R., Holtzapple, M. T., Shi, J., Ebrik, M. A., Redmond, T., Yang, B., Wyman, C. E., Warner, R. E. (2011): Comparative study on enzymatic digestibility of switchgrass varieties and harvests processed by leading pretreatment technologies. - Bioresource Technology 102: 11089-11096.

[87] Kimura, E., Collins, H. P., Fransen, S. (2015): Biomass production and nutrient removal by switchgrass (Panicum virgatum) under irrigation. - Agronomy Journal 107: 204-210. 
[88] Krupinsky, J. M., Berdahl, J. D., Schoch, C. L., Rossman, A. Y. (2004): Leaf spot on switch grass (Panicum virgatum), symptoms of a new disease caused by Bipolaris oryzae. - Canadian Journal of Plant Pathology 26: 371-378. https://doi.org/10.1080/07060660409507155.

[89] Kumar, H., Mohapatra, S. K., Singh, R. I. (2017): Review on CFD Modelling of Fluidized Bed Combustion Systems based on Biomass and Co-firing. - Journal of The Institution of Engineers (India): Series C: 1-26. https://doi.org/10.1007/s40032-017-03612.

[90] Kupryś-Caruk, M. P. (2017): The effect of microbial silage additives on biogas production from perennial energy grasses. - Journal of Research and Applications in Agricultural Engineering 62: 68-71.

[91] Kurylenko, O. O., Ruchala, J., Hryniv, O. B., Abbas, C. A., Dmytruk, K. V., Sibirny, A. A. (2014): Metabolic engineering and classical selection of the methylotropic thermotolerant yeast Hansenula polymorpha for improvement of high-temperature xylose alcoholic fermentation. - Microbial Cell Factories 13: 122-132.

[92] Larsen, S., Bruun, S., Lindedam, J. (2012): Straw yield and saccharification potential for ethanol in cereal species and wheat cultivars. - Biomass and Bioenergy 45: 239-250.

[93] Lee, H. V., Hamid, S. B. A., Zain, S. K. (2014a): Conversion of lignocellulosic biomass to nanocellulose: structure and chemical process. - The Scientific World Journal, Article ID: 631013. DOI: $10.1155 / 2014 / 631013$.

[94] Lee, D. K., Parrish, A. S., Voigt, T. B. (2014b): Switchgrass and Giant Miscanthus Agronomy. - In: Shastri, Y., Hansen, A., Rodriguez, L., Ting, K. C. (eds.) Engineering and Science of Biomass Feedstock Production and Provision. Springer, New York.

[95] Lemus, R., Brummer, E. C., Burras, C. L., Moore, K. J., Barker, M. F., Molstad, N. E. (2008): Effects of nitrogen fertilization on biomass yield and quality in large fields of established switchgrass in southern Iowa, USA. - Biomass and Bioenergy 32: 1187-1194.

[96] Lewandowski, I., Kicherer, A. (1997): Combustion quality of biomass: Practical relevance and experiments to modify the biomass quality of Miscanthus $x$ giganteus. European Journal of Agronomy 6: 163-177.

[97] Lewandowski, I., Scurlock, J. M. O., Lindvall, E., Christou, M. (2003): The development and current status of perennial rhizomatous grasses as energy crops in the US and Europe. - Biomass and Bioenergy 25: 335-361.

[98] Liebig, M. A., Schmer, M. R., Vogel, K. P., Mitchell, R. B. (2008): Soil carbon storage by switchgrass grown for bioenergy. - BioEnergy Research 1: 215-222.

[99] Lindsey, K., Johnson, A., Kim, P., Jackson, S., Labbe, N. (2013): Monitoring switchgrass composition to optimize harvesting periods for bioenergy and value-added products. Biomass and Bioenergy 56: 29-37.

[100] Liu, X.-J. A., Fike, J. H., Galbraith, J. M., Fike, W. B. (2014): Switchgrass Response to Cutting Frequency and Biosolids Amendment: Biomass Yield, Feedstock Quality, and Theoretical Ethanol Yield. - BioEnergy Research 7: 1191-1200.

[101] Liu, J., Wang, Y., Wang, X., Cao, Z., Li, S., Cui, Z. (2016): The effect of Lactobacillus brevis and fibrolytic enzymes on fermentation of switchgrass silages. - Journal of Animal Science 94(5): 320. https://doi.org/10.2527/jam2016-0670.

[102] Loow, Y.-L., Wu, T. Y., Md. Jahim, J., Mohammad, A. W., Teoh, W. H. (2016): Typical conversion of lignocellulosic biomass into reducing sugars using dilute acid hydrolysis and alkaline pretreatment. - Cellulose 23: 1491-1520.

[103] Madakadze, I. C., Stewart, K., Peterson, P. R., Coulman, B. E., Smith, D. L. (1999): Switchgrass biomass and chemical composition for biofuel in eastern Canada. Agronomy Journal 91: 696-701.

[104] Majtkowski, W. (2006): Biodiversity of energetic crops as a basis for sustainable development. - Problemy Inżynierii Rolniczej 2: 25-36 (in Polish). 
[105] McLaughlin, S. B., Kszos, L. A. (2005): Development of switchgrass (Panicum virgatum) as a bioenergy feedstock in the United States. - Biomass and Bioenergy 28: 515-535.

[106] McLaughlin, S. B., De La Torre Ugarte, D. G., Garten, C. T., Lynd, L. R., Sanderson, M. A., Tolbert, V. R., Wolf, D. D. (2002): High-value renewable energy from prairie grasses. - Environmental Science \& Technology 36: 2122-2129.

[107] Miesel, J. R., Renz, M. J., Doll, J. E., Jackson, R. D. (2012): Effectiveness of weed management methods in establishment of switchgrass and a native species mixture for biofuels in Wisconsin. - Biomass and Bioenergy 36: 121-131.

[108] Miesel, J. R., Jach-Smith, L. C., Renz, M. J., Jackson, R. D. (2017): Distribution of switchgrass (Panicum virgatum L.) aboveground biomass in response to nitrogen addition and across harvest dates. - Biomass and Bioenergy 100: 74-83.

[109] Min, D., Guragain, Y. N., Prasad, V., Vadlani, P. V., Lee, J. (2017): Effects of Different Genotypes of Switchgrass as a Bioenergy Crop on Yield Components and Bioconversion Potential. - Journal of Sustainable Bioenergy Systems 7: 27-35.

[110] Mitchell, R. B., Schmer, M. (2012): Switchgrass Harvest and Storage. - In: Monti, A. (ed.) Switchgrass: A Valuable Biomass Crop for Energy. Springer-Verlag, London.

[111] Mitchell, R. B., Vogel, K. P., Sarath, S. (2008): Managing and enhancing switchgrass as a bioenergy feedstock. - Biofuels, Bioproducts and Biorefining 2: 530-539.

[112] Mitchell, R., Lee, D. K., Casler, M. (2014): Switchgrass. - In: Karlen, D. L. (ed.) Cellulosic Energy Cropping Systems. John Wiley \& Sons, Lincoln.

[113] Mitchell, R. B., Vogel, K. P., Schmer, M. (2016): Switchgrass (Panicum virgatum) for Biofuel Production. - http://articles.extension.org/pages/26635/switchgrass-panicumvirgatum-for-biofuel-production (accessed in May, 2018).

[114] Mohamed, B. A., Kim, Ch. S., Ellis, N., Bi, X. (2016): Microwave-assisted catalytic pyrolysis of switchgrass for improving bio-oil and biochar properties. - Bioresource Technology 201: 121-132.

[115] Mohammed, T. A., Raun, W., Kakani, G., Zhang, H., Taylor, R., Desta, K. G., Jared, C., Mullock, J., Bushong, J., Sutradhar, A., Ali, M. S., Reinert, M. (2015): Nutrient sources and harvesting frequency on quality biomass production of switchgrass (Panicum virgatum L.) for biofuel. - Biomass and Bioenergy 81: 242-248.

[116] Monti, A., Fazio, S., Venturi, G. (2009a): Cradle-to-farm gate life cycle assessment in perennial energy crops. - European Journal of Agronomy 31: 77-84.

[117] Monti, A., Fazio, S., Venturi, G. (2009b): The discrepancy between plot and field yields: Harvest and storage losses of switchgrass. - Biomass and Bioenergy 33: 841-847.

[118] Moser, L. E., Vogel, K. P. (1995): Switchgrass, Big Bluestem, and Indiangrass. - In: Barnes, R. F., Miller, D. A., Nelson, C. J. (eds.) An Introduction to Grassland Agriculture. Forages, 5th ed. Vol.1. Iowa University Press, Ames, IA.

[119] Muir, J. P., Sanderson, P. A., Ocumpaugh, W. R., Jones, R. M., Reed, R. L. (2001): Biomass production of "Alamo" switchgrass in response to nitrogen, phosphorus and row sparing. - Agronomy Journal 93: 896-901.

[120] Papa, G., Rodriguez, S., George, A., Schievano, A., Orzi, V., Sale, K. L., Singh, S., Adani, F., Simmons, B. A. (2015): Comparison of different pretreatments for the production of bioethanol and biomethane from corn stover and switchgrass. Bioresource Technology 183: 101-110.

[121] Pardo-Planas, O., Atiyeh, H. K., Phillips, J. R., Aichele, C. P., Mohammad, S. (2017): Process simulation of ethanol production from biomass gasification and syngas fermentation. - Bioresource Technology 245: 925-932.

[122] Parrish, D., Fike, J. (2005): The biology and agronomy of switchgrass for biofuels. Critical Reviews in Plant Sciences 24: 423-459. https://doi.org/10.1080/07352680500316433.

[123] Pasangulapati, V., Ramachandriya, K. D., Kumar, A., Wilkins, M. R., Jones, C. L., Huhnke, R. L. (2012): Effects of cellulose, hemicellulose and lignin on thermochemical 
conversion characteristics of the selected biomass. - Bioresource Technology 114: 663669.

[124] Piechocki, J., Sołowiej, P., Neugebauer, M. (2010): Gasification of waste biomass from agricultural production. - Agricultural Engineering 5: 219-224 (in Polish).

[125] Pilon, G., Lavoie, J.-M. (2011): Characterization switchgrass char produced in torrefaction and pyrolysis conditions. - BioResources 6: 4824-4839.

[126] Pilon, G., Lavoie, J.-M. (2013): Pyrolysis of switchgrass (Panicum virgatum L.) at low temperatures in $\mathrm{N}_{2}$ and $\mathrm{CO}_{2}$ environments; a study on chemical composition of chars extracts and bio-oils. - Journal of Analytical and Applied Pyrolysis 101: 122-131.

[127] Pimentel, D., Patzel, T. W. (2005): Ethanol production using corn, switchgrass, and wood; biodiesel production using soybean and sunflower. - Natural Resources Research 14: 65-76.

[128] Prasifka, J. R., Bradshaw, J. D., Boe, A. A., Lee, D., Adamski, D., Gray, M. E. (2010): Symptons, distribution, and abundance of the stem-boring caterpillar, Blastobasis repartella (Dietz), in switchgrass. - BioEnergy Research 3: 238-242.

[129] Prieto, G. S., Ernst, O., Bustamante, M. (2017): Impact of harvest frequency on biomass yield and nutrient removal of elephantgrass, giant reed, and switchgrass. - BioEnergy Research 10: 853-863.

[130] Pszczółkowski, A., Romanowska-Duda, Z., Pszczółkowska, A., Grzesik, M., Wysokińska, Z. (2012): Biomass production of selected energy plants: economic analysis and logistic strategies. - Comparative Economic Research. Central and Eastern Europe 15: 77-103.

[131] Qian, K., Kumar, A., Patil, K. N., Bellmer, D. D., Wang, D., Yuan, W., Huhnke, R. L. (2013): Effects of biomass feedstocks and gasification conditions on the physiochemical properties of char. - Energies 6: 3972-3986. DOI: 10.3390/en6083972.

[132] Qin, X., Mohan, T., El-Halwagi, M., Cornforth, G., McCarl, B. A. (2006): Switchgrass as an alternate feedstock for power generation: an integrated environmental, energy and economic life-cycle assessment. - Clean Technologies and Environmental Policy 8: 233249.

[133] Quinn, L. D., Straker, K. C., Guo, J., Kim, S., Thapa, S., Kling, G., Lee, D., Voigt, T. B. (2015): Stress-tolerant feedstocks for sustainable bioenergy production on marginal land. - BioEnergy Research 8: 1081-1100.

[134] Rajendran, K., Drielak, E., Varma, V. S., Muthusamy, S., Kumar, G. (2018): Updates on the pretreatment of lignocellulosic feedstocks for bioenergy production-a review. Biomass Conversion and Biorefinery 8(2): 471-483. DOI 10.1007/s13399-017-0269-3.

[135] Rijal, B., Igathinathane, C., Karki, B., Yu, M., Pryor, S. W. (2012): Combined effect of pelleting and pretreatment on enzymatic hydrolysis of switchgrass. - Bioresource Technology 116: 36-41.

[136] Rodriguez, C., Alaswad, A., Benyounis, K. Y., Olabi, A. G. (2017): Pretreatment techniques used in biogas production from grass. - Renewable and Sustainable Energy Reviews 68(2): 1193-1204.

[137] Sadeghpour, A., Gorlitsky, L. E., Hashemi, M., Weis, S. A., Herbert, S. J. (2014a): Response of switchgrass yield and quality to harvest season and nitrogen fertilizer. Agronomy Journal 106: 290-296.

[138] Sadeghpour, A., Hashemi, M., DaCosta, M., Jahanzad, E., Herbert, S. J. (2014b): Switchgrass establishment influenced by cover crop, tillage systems, and weed control. BioEnergy Research 7: 1402-1410.

[139] Samson, R. (2007): Switchgrass production in Ontario: A management guide. Resource Efficient Agricultural Production (REAP) - Canada http://www.reapcanada.com/online_library/grass_pellets/2007\%20SG\%20production\%20guideFINAL.pd f> (accessed in May, 2018).

[140] Sanderson, M. A., Adler, P. R. (2008): perennial forages as second generation bioenergy crops. - International Journal of Molecular Sciences 9: 768-788. 
[141] Sanderson, M. A., Reed, R. L., McLaughlin, S. B., Wullschleger, S. D., Conger, B. V., Parrish, D. J., Wolf, D. D., Taliaferro, C., Hopkins, A. A., Ocumpaugh, W. R., Hussey, M. A., Read, J. C., Tischler, C. R. (1996): Switchgrass as a sustainable bioenergy crop. Bioresource Technology 56: 83-93.

[142] Sanderson, M. A., Adler, P. R., Boateng, A. A., Casler, M. D., Sarath, G. (2006): Switchgrass as a biofuels feedstock in the USA. - Canadian Journal of Plant Science 86: 1315-1325.

[143] Sanderson, M. A., Schmer, M., Owens, V., Keyser, P., Elbersen, W. (2012): Crop Management of Switchgrass. - In: Monti, A. (ed.) Switchgrass: A Valuable Biomass Crop for Energy. Springer-Verlag, London.

[144] Sarkar, M., Kumar, A., Tumuluru, J. S., Patil, K. N., Bellmer, D. D. (2014): Gasification performance of switchgrass pretreated with torrefaction and densification. - Applied Energy 127: 194-201.

[145] Schmer, M. R., Vogel, K. P., Mitchell, R. B., Moser, L. E., Eskridge, K. M., Perrin, R. K. (2006): Establishment stand thresholds for switchgrass grown as a bioenergy crop. - Crop Science 46: 157-161.

[146] Schmer, M. R., Vogel, K. P., Mitchell, R. B., Perrin, R. K. (2008): Net energy of cellulosic ethanol from switchgrass. - Proceedings of the National Academy of Sciences 105(2): 464-469.

[147] Schmer, M. R., Vogel, K. P., Varvel, G. E., Follett, R. F., Mitchell, R. B., Jin, V. L. (2014): Energy potential and greenhouse gas emissions from bioenergy cropping systems on marginally productive cropland. - PLoS ONE 9(3): e89501. https://doi.org/10.1371/journal.pone.0089501.

[148] Scordia, D., Zanetti, F., Varga, Sz. S., Alexopoulou, E., Cavallaro, V., Monti, A., Copani, V., Cosentino, S. L. (2015): New Insights into the propagation methods of switchgrass, miscanthus and giant reed. - Bioenergy Research 8: 1480-1491.

[149] Sekutowski, T., Rola, J., Kaus, A. (2009): Weed Communities Occurring in Newly Established Plantations of Crops Used for Energy Purposes and Methods for Their Reduction. - In: Skrobacki, A. (ed.) Biomass Production - Selected Problems. Wyd. Wieś Jutra, Warszawa (in Polish).

[150] Serapiglia, M. J., Bruce, S., Dien, B. S., Boateng, A. A., Casler, M. D. (2017): Impact of harvest time and switchgrass cultivar on sugar release through enzymatic hydrolysis. BioEnergy Research 10: 377-387.

[151] Sharma, S., Sharma, V., Kuila, A. (2016): Cellulase production using natural medium and its application on enzymatic hydrolysis of thermo chemically pretreated biomass. -3 Biotech 6: 139. DOI 10.1007/s13205-016-0465-z.

[152] Shield, I. F., Barraclough, T. J. P., Riche, A. B., Yates, N. E. (2012): The yield response of the energy crops switchgrass and reed canary grass to fertiliser applications when grown on a low productivity sandy soil. - Biomass and Bioenergy 42: 86-96.

[153] Smeets, E. M. W., Lewandowski, I. M., Faaij, A. P. C. (2009): The economical and environmental performance of miscanthus and switchgrass production and supply chains in a European setting. - Renewable \& Sustainable Energy Reviews 13: 1230-1245.

[154] Sokhansanj, S., Mani, S., Turhollow, A., Kumar, A., Bransby, D., Lynd, L., Laser, M. (2009): Large-scale production, harvest and logistics of switchgrass (Panicum virgatum L.) - current technology and envisioning a mature technology. - Biofuels, Bioproducts and Biorefining 3: 124-141.

[155] Steward, C. L., Pyle, J. D., Jochum, C. C., Vogel, K. P., Yuen, G. Y., Scholthof, K.-B. G. (2015): Multi-year pathogen survey of biofuel switchgrass breeding plots reveals high prevalence of infections by Panicum mosaic virus and its satellite virus. Phytopathology 105: 1146-1154. http://dx.doi.org/10.1094/PHYTO-03-15-0062-R.

[156] Suryawati, L., Wilkins, M. R., Bellmer, D. D., Huhnke, R. L., Maness, N. O., Banat, I. M. (2008): Simultaneous saccharification and fermentation of Kanlow switchgrass pretreated 
by hydrothermolysis using Kluyveromyces marxianus IMB4. - Biotechnology and Bioengineering 101(5): 894-902.

[157] Suryawati, L., Wilkins, M. R., Bellmer, D. D., Huhnke, R. L., Maness, N. O., Banat, I. M. (2009): Effect of hydrothermolysis process conditions on pretreated switchgrass composition and ethanol yield by SSF with Kluyveromyces marxianus IMB4. - Process Biochemistry 44: 540-545.

[158] Sykes, V. R., Allen, F. L., Mielenz, J. R., Stewart Jr., C. N., Windham, M. T., Hamilton, Ch. Y., Rodriguez Jr., M., Yee, K. L. (2016): Reduction of ethanol yield from switchgrass infected with rust caused by Puccinia emaculata. - BioEnergy Research 9(1): 239-247. DOI $10.1007 / \mathrm{s} 12155-015-9680-4$. https://bioenergycenter.org/besc/publications/sykes_reduction_yr9.pdf (accessed in July, 2018).

[159] Tanner, R. S. (2008): Production of Ethanol from Synthesis Gas. - In: Wall, J. D., Harwood, C. S., Demain, A. L. (eds.) Bioenergy. ASM Press, Washington.

[160] Thamsiriroj, T., Nizami, A. S., Murphy, J. D. (2012): Why does mono-digestion of grass silage fail in long term operation? - Applied Energy 95: 64-76.

[161] Thomason, W. E., Raun, W. R., Johnson, G. V., Taliaferro, C. M., Freeman, K. W., Wynnum, K. J., Mullen, R. W. (2004): Switchgrass response to harvest frequency and time and rate of applied nitrogen. - Journal of Plant Nutrition 27: 1199-1226.

[162] Thomsen, P. M., Brummer, E. C., Shriver, J., Munkvold, G. P. (2008): Biomass yield reductions in switchgrass due to smut caused by Tilletia maclaganii. - Plant Health Progress. DOI: 10.1094/PHP-2008-0317-01-RS. https://www.plantmanagementnetwork.org/pub/php/research/2008/smut/ (accessed in July, 2018).

[163] Tillman, D. A. (2000): Biomass co-firing: the technology, the experience, the combustion consequences. - Biomass and Bioenergy 19: 365-384.

[164] Torreiro, Y., Pérez, V., Murillo, J. M., Ramos, R., Fernández, M., García, S., Sáncheza, J. M. (2018): Thermochemical assessment of Nicotiana glauca, Panicum virgatum and Elytrigia elongata as fuels for energy recovery through gasification. - Fuel 225: 71-79.

[165] Umezawa, T. (2018): Lignin modification in planta for valorization. - Phytochemistry Reviews 1-23. https://doi.org/10.1007/s11101-017-9545-x.

[166] Uppalapati, S. R., Serba, D. D., Ishiga, Y., Szabo, L. J., Mittal, S., Bhandari, H. S., Bouton, J. H., Mysore, K. S., Saha, M. C. (2013): Characterization of the rust fungus, Puccinia emaculata, and evaluation of genetic variability for rust resistance in switchgrass populations. - BioEnergy Research 6: 458-468.

[167] Vamvuka, D., Topouzi, V., Sfakiotakis, S. (2010): Evaluation of production yield and thermal processing of switchgrass as a bio-energy crop for the Mediterranean region. Fuel Processing Technology 91: 988-996.

[168] Vogel, K. P. (2004): Switchgrass. - In: Moser, L. E., Burson, B. L., Sollenberger, L. E. (eds.) Warmseason (C4) Grasses. ASA-CSSA-SSSA, Madison.

[169] Vogel, K. P., Brejda, J. J., Walters, D. T., Buxton, D. R. (2002): Switchgrass biomass production in the Midwest USA: harvest and nitrogen management. - Agronomy Journal 94: 413-420.

[170] Vogel, K. P., Sarath, G., Saathoff, A. J., Mitchell, R. B. (2011): "Switchgrass". $\begin{array}{lllll}\text { Agronomy \& } \quad \text { Horticulture Faculty } & \text { Publications } & 1028 .\end{array}$ http://digitalcommons.unl.edu/agronomyfacpub/1028 (accessed in May, 2018).

[171] Vu, A. L., Dee, M. M., Gualandi, R. J., Huff, S., Zale, J., Gwinn, K. D., Ownley, B. H. (2011): First report of leaf spot caused by Bipolaris spicifera on switchgrass in the United States. - Plant Disease 95: 1191. https://apsjournals.apsnet.org/doi/10.1094/PDIS-10-100774 (accessed in July, 2018).

[172] Wang, C., Guo, L., Li, Y., Wang, Z. (2012): Systematic comparison of C3 and C4 plants based on metabolic network analysis. - BMC Systems Biology 6 Suppl. 2: S9. DOI: 10.1186/1752-0509-6-S2-S9. 
[173] Wang, Z., Smyth, T. J., Crozier, C. R., Gehl, R. J., Heitman, A. J. (2018): Yield and nitrogen removal of bioenergy grasses as influenced by nitrogen rate and harvest management in the coastal plain region of North Carolina. - BioEnergy Research 11: 4453.

[174] Waramit, N., Moore, K. J., Heggenstaller, A. H. (2011): Composition of native warmseason grasses for bioenergy production in response to nitrogen fertilization rate and harvest date. - Agronomy Journal 103: 655-662.

[175] Wayman, S., Bowden, R. D., Mitchell, R. B. (2014): Seasonal changes in shoot and root nitrogen distribution in switchgrass (Panicum virgatum). - BioEnergy Research 7: 243252.

[176] Williams, C. L., Westover, T. L., Emerson, R. M., Tumuluru, J. S., Li, Ch. (2016): Sources of biomass feedstock variability and the potential impact on biofuels production. - BioEnergy Research 9: 1-14.

[177] Withers, K. K. (2010): Establishment, fertility and harvest management for optimizing switchgrass yield and quality as a cellulosic ethanol feedstock in the Great Lakes region. - Crop and Soil Science, M.S. Thesis, Michigan State University.

[178] Wullschleger, S. D., Davis, E. B., Borsul, M. E., Gunderson, C. A., Lynd, L. R. (2010): Biomass production in switchgrass across the United States: Database description and determinants of yield. - Agronomy Journal 102: 1158-1168.

[179] Xu, J., Wang, Z., Sharma-Shivappa, R. R., Cheng, J. J. (2011): Enzymatic hydrolysis of switchgrass and coastal Bermuda grass pretreated using different chemical method. BioResources 6: 2990-3003.

[180] Yee, K. L., Rodriguez Jr., M., Thompson, O. A., Fu, Ch., Wang, Z.-Y., Davison, B. H., Mielenz, J. R. (2014): Consolidated bioprocessing of transgenic switchgrass by an engineered and evolved Clostridium thermocellum strain. - Biotechnology for Biofuels 7: 75.

DOI:10.1186/1754-6834-7-75. http://www.biotechnologyforbiofuels.com/content/7/1/75 (accessed in July, 2018)

[181] Young, H. A., Sarath, G., Tobias, C. M. (2012): Karyotype variation is indicative of subgenomic and ecotypic differentiation in switchgrass. - BMC Plant Biology 12: 117. DOI: $10.1186 / 1471-2229-12-117$.

[182] Zabed, H., Sahu, J., Suely, A., Boyce, A., Faruq, G. (2017): Bioethanol production from renewable sources: current perspectives and technological progress. - Renewable \& Sustainable Energy Reviews 71: 475-501.

[183] Zale, J., Freshour, L., Agarwal, S., Sorochan, J., Ownley, B. H., Gwinn, K. D., Castlebury, L. A. (2008): First report of rust on switchgrass (Panicum virgatum) caused by Puccinia emaculata in Tennessee. - Plant Disease 92: 1710-1710.

[184] Zegada-Lizarazu, W. E., Elbersen, W., Cosentino, S. L., Zatta, A., Alexopoulou, E., Monti, A. (2010): Agronomic aspects of future energy crops in Europe. - Biofuels, Bioproducts and Biorefining 4: 674-691.

[185] Zhao, X., Liu, J., Liu, J., Yang, F., Zhu, W., Yuan, X., Hu, Y., Cui, Z., Wang, X. (2017): Effect of ensiling and silage additives on biogas production and microbial community dynamics during anaerobic digestion of switchgrass. - Bioresource Technology 241: 349359.

[186] Zheng, Z., Liu, J., Yuan, X., Wang, X., Zhu, W., Yang, F., Cui, Z. (2015): Effect of dairy manure to switchgrass co-digestion ratio on methane production and the bacterial community in batch anaerobic digestion. - Applied Energy 151: 249-257.

[187] Zorer Çelebi, Ş., Zorer, Ö. S. (2018): Accumulation and tolerance of $\mathrm{Pb}$ in some bioenergy crops. - Polish Journal of Environmental Studies 27: 591-596.

[188] Zuwała, J., Kopczyński, M., Robak, J. (2014): Coupled torrefaction-pelletization process for biomass co-firing, techno-economic issues. - Polityka energetyczna T.17 z.4: 147-158 (in Polish). 